\title{
Multiple damage zone structure of an exhumed seismogenic megasplay fault in a subduction zone - a study from the Nobeoka Thrust Drilling Project
}

Mari Hamahashi ${ }^{1 *}$, Yohei Hamada², Asuka Yamaguchi ${ }^{3}$, Gaku Kimura ${ }^{1,4}$, Rina Fukuchi ${ }^{3}$, Saneatsu Saito ${ }^{4}$, Jun Kameda ${ }^{5}$, Yujin Kitamura ${ }^{6}$, Koichiro Fujimoto ${ }^{7}$ and Yoshitaka Hashimoto ${ }^{8}$

\begin{abstract}
To investigate the mechanical properties and deformation patterns of megathrusts in subduction zones, we studied damage zone structures of the Nobeoka Thrust, an exhumed megasplay fault in the Kyushu Shimanto Belt, using drill cores and geophysical logging data obtained during the Nobeoka Thrust Drilling Project. The hanging wall, composed of a turbiditic sequence of phyllitic shales and sandstones, and the footwall, consisting of a mélange of a shale matrix with sandstone and basaltic blocks, exhibit damage zones that include multiple sets of 'brecciated zones' intensively broken in the mudstone-rich intervals, sandwiched by 'surrounding damage zones' in the sandstone-rich intervals with cohesive faults and mineral veins. The fracture zones are thinner ( 2.7 to $5.5 \mathrm{~m}$ ) in the sandstone-rich intervals and thicker in the shale-dominant intervals (2.3 to $18.6 \mathrm{~m}$ ), which indicates a preference of coseismic slip and velocity-weakening in the former, and aseismic deformation in the latter. However, the surrounding damage zones observed in the current study are associated with an increase in resistivity, $P$-wave velocity, and density and a decrease in porosity, inferring densification and strain-hardening in the sandstone-rich intervals and strain-weakening in the mudstone-rich intervals. These observations indicate that the sandstone-rich damage zones may weaken in the short term but may strengthen in the geologically long term, contributing to a later stage of fault activity. In contrast, the mudstone-rich damage zones may strengthen in the short term but develop weak structures through longer time periods. The observed shear zone thickness in the hanging wall is thinner ( 2.3 to $18.6 \mathrm{~m}$ ) compared to the footwall damage zones (12 to $39.9 \mathrm{~m}$ ), possibly because faults in the hanging wall were concentrated and partitioned between the preexisting turbiditic sequence of alternating shale/ sandstone-dominant intervals, whereas in the footwall, faults were more sporadically distributed throughout the sandstone block-in-matrix cataclasites. A splay fault may evolve and be characterized by physical property contrasts, the lithology dependence of deformation, and the variability of damage zone thickness due to a heterogeneous lithology distribution in the hanging wall and footwall. The deformation patterns observed in the Nobeoka Thrust provide insights to the strain-hardening/weakening behaviors of sediments along megathrusts over geological timescales.
\end{abstract}

Keywords: Subduction zone; Megasplay fault; Shimanto Belt; Physical property; Damage zone; Nobeoka Thrust

\footnotetext{
*Correspondence: m_hamahashi@eps.s.u-tokyo.ac.jp

${ }^{1}$ Department of Earth and Planetary Science, Graduate School of Science, The University of Tokyo, 7-3-1 Hongo, Bunkyo-ku, Tokyo 113-0033, Japan Full list of author information is available at the end of the article
} 


\section{Background}

Shear localization in foliated, phyllosilicate-rich fault rocks is known to cause weakening in crustal fault zones (e.g., Stewart et al. 2000; Imber et al. 2001; Gueydan et al. 2003; Collettini and Holdsworth 2004; Wibberley and Shimamoto 2005; Jefferies et al. 2006). Various weakening mechanisms have been proposed including sliding and/or frictional-viscous flow in low-friction phyllosilicate gouges (e.g., Niemeijer and Spiers 2005; Boulton et al. 2012), comminution of rock material and grain size reduction (e.g., De Bresser et al. 2001), fault lubrication (e.g., Di Toro et al. 2011), high pore fluid pressures (e.g., Smith et al. 2008), fluid-enhanced reaction weakening (e.g., Wibberley and Shimamoto 2005), thermal pressurization (e.g., Brodsky and Kanamori 2001), and thermal melting (e.g., Leloup et al. 1999). In subduction zones, the strength profile is additionally influenced by mechanisms such as compaction through tectonic loading, mineral dehydration, and fluid release occurring along the plate boundary (e.g., Saffer and Tobin 2011). Due to the complicated structures of fault zones and the differences in mechanical strength contrast across the decollement, overriding wedge, and underthrust material, the development of phyllosilicaterich fault rocks may occur heterogeneously. The issue of whether foliated fault rocks distributed along megathrusts behave as weak structures for geologically long terms remains unresolved, as does their relationship with different lithologies. The roles of foliated fault rocks in the process of strain localization and fault evolution in subduction zone settings are poorly understood.

Exhumed fault zones are helpful to constrain fault strength and the deformation of foliated cataclasites formed at middle crustal depths over geological time. Foliated fault rocks in subduction settings are particularly well exposed in ancient subduction complexes. One well-studied exhumed major fault zone in a subduction setting is the Nobeoka Thrust in the Kyushu Shimanto Belt, southwest Japan, which is a fossilized subduction zone megasplay fault (e.g., Kimura 1998) that incurred large displacement of 8.6 to $14.4 \mathrm{~km}$ and exposes foliated fault rocks formed at temperatures of $150^{\circ} \mathrm{C}$ to $350^{\circ} \mathrm{C}$ (Kondo et al. 2005).

In addition to previous studies on the outcrop of the Nobeoka Thrust, scientific drilling and downhole geophysical logging were conducted in 2011 to acquire continuous cores and to determine physical property values of the fault rocks (Hamahashi et al. 2013; Fukuchi et al. 2014). The drilled cores exhibit several damage zones that contain both consolidated fault rocks and less consolidated, brecciated fault rocks, which were preserved from surface weathering and where brecciation was unlikely to be drilling-induced. These damage zones provide a different aspect of fault rock strength compared to previous geological studies of exposed, consolidated outcrops where brecciated rocks are rarely found. In the present study, we synthesized results from drilled cores and geophysical logs of the Nobeoka Thrust to characterize damage zone structures by examining the relationships among physical properties, lithology, and fracture density of the fault rocks.

\section{Geologic setting of the Nobeoka Thrust}

The Japanese islands are situated on the western Pacific convergent margin and were formed through subduction and accretion processes (e.g., Maruyama et al. 1997; Taira et al. 1989). The Shimanto Belt is an ancient accretionary complex formed during the Cretaceous and Tertiary periods and is now exposed in southwest Japan parallel to the trench axis of the Nankai Trough. The Shimanto Belt is divided into a northern and southern section by a major boundary fault called the Aki Tectonic Line in the Shikoku and Kii regions and the Nobeoka Thrust in Kyushu (Imai et al. 1971). The Nobeoka Thrust is well exposed along the coastline in the Miyazaki Prefecture and is responsible for the exhumation of the deeper Morotsuka and Kitagawa groups (hanging wall) in the north onto the shallower Hyuga group (footwall) in the south (Kondo et al. 2005; Okamoto et al. 2006, 2007; Raimbourg et al. 2009). Thermal structures along the Nobeoka Thrust studied by vitrinite reflectance, fluid inclusion, illite crystallinity, and fission-track analyses indicated that the maximum experienced temperatures of the hanging wall and footwall are approximately $320^{\circ} \mathrm{C}$ and $250^{\circ} \mathrm{C}$, respectively (Kondo et al. 2005; Hara and Kimura 2008; Raimbourg et al. 2009). This thermal gap across the fault suggests that the Nobeoka Thrust had been active as an out-of-sequence-thrust or megasplay fault at depths of several to $11 \mathrm{~km}$ beneath the sea bottom surface (Kondo et al. 2005). Assuming a geothermal gradient of 28 to $47^{\circ} \mathrm{C} \mathrm{km}^{-1}$ and a fault dip angle of approximately $10^{\circ}$, the thermal gap corresponds to 8.6 to $14.4 \mathrm{~km}$ displacement along the thrust in the seismogenic zone (Kondo et al. 2005). A large displacement of several kilometers along the splay fault at similar depths in the modern Nankai Trough is also suggested from the tilting of the forearc basin sediments observed in seismic images (Park et al. 2002).

The hanging wall rock of the Nobeoka Thrust is composed of a turbiditic sequence of alternating layers of phyllitic shales and sandstones from the Eocene Kitagawa Group (Kondo et al. 2005). Kondo et al. (2005) conducted microstructural observations on samples from the outcrop and documented that the shale-dominated zones were deformed by pressure solution whereas plastic flow associated with dynamic recrystallization of quartz aggregates occurred in the sandstones and mineral veins. Horizontal slaty cleavage associated with these frictional-viscous deformations is almost parallel to the main fault core of the 
Nobeoka Thrust, and these cleavages are inferred to have experienced vertical maximum principle stress conditions during deep burial (Raimbourg et al. 2009; Kameda et al. 2011; Kimura et al. 2013).

The Nobeoka Thrust is characterized by a fault core of approximately 25- to 80-cm-thick cataclasite with a highly deformed random fabric, as well as fragmented sandstones with partial plastic deformation and pressure solution within quartz aggregates, similar to the sandstones in the footwall (Kondo et al. 2005; Kimura et al. 2013). The fault core is bordered by phyllite overprinted by a brittle shear zone of several meter thickness in the hanging wall (Kondo et al. 2005; Kimura et al. 2013) and a footwall with a thickness of about $100 \mathrm{~m}$ (Kondo et al. 2005; Yamaguchi et al. 2011). Within the brittle damage zone of the hanging wall, pseudotachylyte-bearing faults and tension-crack-filling veins exist at high angles to the cleavage (Okamoto et al. 2006, 2007; Kimura et al. 2013).

The footwall strata of the Eocene to early Oligocene Hyuga Group are composed of a mélange of shale matrix with sandstone and basaltic blocks deformed in a brittle manner (Kondo et al. 2005). The deformation of fault rocks in the footwall is brittle deformation accompanied by pressure solution as inferred from microstructural observations on quartz aggregates in sandstone blocks (Kondo et al. 2005). Subsidiary fractures and a cataclastic composite planar fabric are categorized into types Y, R, P, and T (Logan et al. 1981; Chester and Logan 1986) and are occasionally filled by mineral veins (Kondo et al. 2005; Yamaguchi et al. 2011).

The Nobeoka Thrust Drilling Project (NOBELL) was begun in 2011 (Figure 1) to clarify the deformation patterns of the megasplay fault and to obtain geological and geophysical datasets for integration among previous studies, observations from the outcrop, and ocean drilling of the modern megasplay fault (Hamahashi et al. 2013; Fukuchi et al. 2014). In addition to physical property measurements on samples from the outcrop of the Nobeoka Thrust (Tsuji et al. 2006), Hamahashi et al. (2013) documented physical properties near the main fault core from geophysical logs. Clear structural and physical property contrasts across the thrust were characterized, which are partially due to different maximum burial depths of the hanging wall and footwall (Hamahashi et al. 2013). One of the major unknowns, however, is the difference in thickness and magnitude of the brittle shear zones across the fault. The thickness of the brittle damage zone near the fault core is a few to several meters in the hanging wall but as large as $100 \mathrm{~m}$ in the footwall. Investigation of the variability of damage zone thickness is essential to understand the fault mechanism of megasplay faults and is an important goal of this study. Damage zones in the hanging wall are also observed in the modern

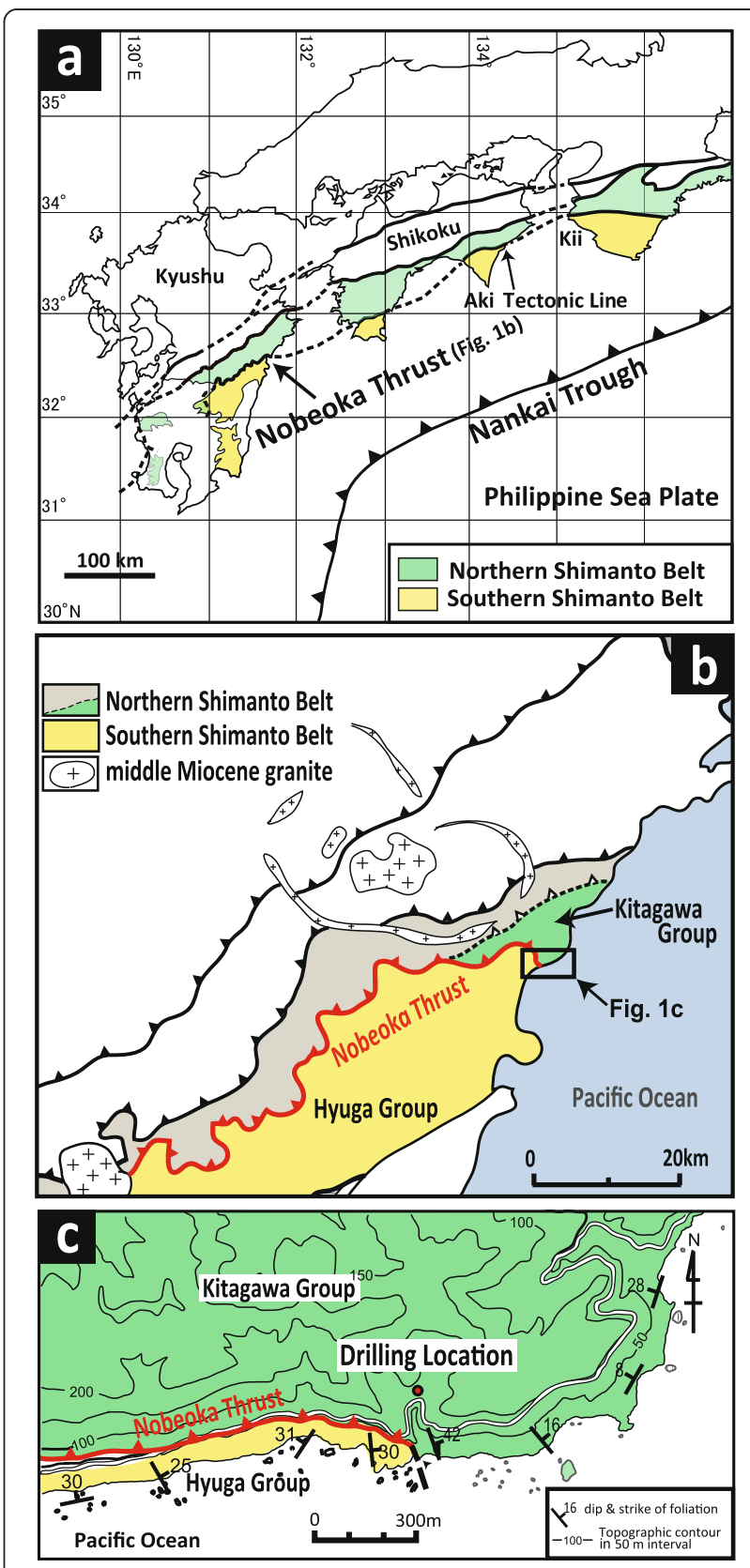

Figure 1 Geologic setting. (a) Geologic setting of the Nobeoka Thrust and distribution of the Shimanto Belt in southwest Japan. (b) A simplified geologic map of the Shimanto Belt in northeast Kyushu, modified from Murata (1998). (c) Geologic map of the studied area and drilling location (dot) in the Nobeoka Thrust.

splay fault at shallow depths in the Nankai Trough but with much thicker width (e.g., Ujiie and Tsutsumi 2010; Rowe et al. 2013) possibly due to upward fault migration toward the free surface (e.g., Ramsay and Huber 1987) and/or deformation such as ramp-flat thrusting and folding in the thrust sheet in the uppermost part of the crust (e.g., Ramsay 1992; Suppe 1983), whereas the footwall damage zone is more extensive in the Nobeoka Thrust, 
suggesting different conditions affecting faults in shallow and deep settings (Hamahashi et al. 2013). As fault rocks are buried deeper and as displacement accumulates along the fault, the footwall would have a higher porosity and lower effective strength relative to the hanging wall and may consequently develop thick damage zones in the former (Hamahashi et al. 2013).

Notably, despite the contrast observed between the hanging wall and footwall of the Nobeoka Thrust on a macroscopic scale, the resistivity and porosity data from both the hanging wall and footwall can be fit to a single curve using Archie's law, suggesting similarities in pore structures and mineralogy in this low porosity range (Hamahashi et al. 2013). The similarities in deformation patterns across the thrust have not yet been documented, and therefore they are another major aim of this study.

\section{Methods}

Data acquisition and methodology for core-log integration We collected the geological observations and geophysical logging data used in the present study from drilled cores and borehole measurements made during NOBELL (Figure 1). Drilling and coring down to $255 \mathrm{~m}$ below the ground surface (hereafter termed 'mbgs') across the Nobeoka Thrust was conducted from 27 July to 15 September 2011 by the Sumiko Resources Exploration \& Development Co., Ltd (SRED). The drilling site is located approximately $200 \mathrm{~m}$ north of the outcrop along the beach, where the fault line of the Nobeoka Thrust gradually bends in a southeast direction toward the seashore (Figure 1). Examinations of the lithology and structural analyses of cleavage, fractures, faults, mineral veins, bedding, and folding were made for every $1-\mathrm{m}$ core. The orientations of the drilled cores are nearly consistent with the outcrop along the beach and are comparable but may be affected by the gradual bend of the fault when compared to the thrust extending to the west. Geophysical wireline logs were acquired across the Nobeoka Thrust continuously in the borehole at a depth of 11.5 to 254.5 mbgs on 17 to 18 September 2011 by SRED and Raax Co., Ltd. The logging recorded neutron porosity, resistivity, acoustic wave velocity $(\mathrm{Vp}, \mathrm{Vs})$, natural gamma rays, density, caliper, spontaneous potential, and temperature for every $10 \mathrm{~cm}$. Acoustic and optical images were obtained along the borehole to evaluate the presence of bedding, fractures, and faults. Details of the drilling operations are presented in the 'Additional file 1'.

Core images were laid out side by side with logs and borehole images to enable a visual correlation between the core and log data. Thus, better determinations of in situ or drilling-induced structures and the calibration of depth and core orientation eliminating the effect of rotation due to drilling were possible. The primary data sets we examined in this study were neutron porosity, electric resistivity, $P$-wave velocity, density, and natural gamma ray attenuation. Note that the electric resistivity data presented in this study concern the short-normal (SN) resistivity of a shorter distance between the electrodes, one of the three types of vertical electric resistivity data obtained in this project ('Additional file 1'). To characterize the mesoscopic deformation along the Nobeoka Thrust, we used fracture data (structures including fault, fracture, breccia, mineral vein) extracted from the core description and logging data. The fracture density data in this study were binned into $1-\mathrm{m}$ and $10-\mathrm{cm}$ intervals. To evaluate the relationship between physical properties and fault rock distribution, we made cross-plots between the logs and fracture density. We also used cross-plots of neutron porosity and resistivity to determine the pore structure, connectivity of the cracks, percolation thresholds, and hydrologic properties (e.g., Ewing and Hunt 2006; Montaron 2009; Kozlov et al. 2012) along the Nobeoka Thrust. The approximate correlation between porosity and resistivity is empirically known as Archie's law (Archie 1942), which is formulated as:

$$
F=R_{e f f} / R_{f}=b \varphi^{-m}
$$

where $F$ is the formation factor, $R_{\text {eff }}$ is the resistivity of fluid-saturated rock, $R_{f}$ is the resistivity of the fluid within the rock, $\varphi$ is the porosity of the rock, $b$ and $m$ ('cementation exponent') are fitting parameters.

The physical properties of the Nobeoka Thrust presented in this study are taken from the current depth and setting. Porosity, resistivity, and $P$-wave velocity values may be influenced by cracks and fractures opened during unloading. Possible approaches to exclude the effect of cracks opened during exhumation include laboratory experiments under confining pressure and theoretical calculations for velocity and effective stress (Tsuji et al. 2006; 2008). In the current study, we quantified the physical property values of host rocks (intact zones), cohesive damage zones, and brecciated fracture zones. The values for intact zones and cohesive damage zones likely represent the values at depth, which enabled us to distinguish the effect of open fractures by examining the transition of these properties at each zone.

\section{Results}

Fault rock distribution and physical properties Shale-dominant interval, sandstone-dominant interval, and the damage zone in the hanging wall

The hanging wall ( 0 to $41.3 \mathrm{mbgs}$ ) composed of the phyllitic Kitagawa Group (alternating beds of sandstone and shale), mainly consists of six intervals of three different types: (1) shale-dominant intervals characterized by a dense development of phyllitic cleavages, kink folds, 
and quartz vein networks at 0 to $18.6 \mathrm{mbgs}$ (18.6 m thick, hereafter 'sh1'), 24.1 to 26.4 mbgs ( $2.3 \mathrm{~m}$ thick, hereafter 'sh2'), and 29.1 to 38.1 mbgs ( 9 m thick, hereafter 'sh3'); (2) sandstone-dominant intervals with disturbed foliations and 2- to 20-mm thick medium- to fine-grained sandstone boudinage and fractures at 18.6 to $24.1 \mathrm{mbgs}$ ( $5.5 \mathrm{~m}$ thick, hereafter 'sd1') and 26.4 to 29.1 mbgs ( 2.7 m thick, hereafter 'sd2'); and (3) the damage zone above the fault core characterized by cataclastically broken phyllite with thick (approximately 20 to 100-mm) abundant medium- to fine-grained sandstone blocks at 38.1 to $41.3 \mathrm{mbgs}$ ( $3.2 \mathrm{~m}$ thick, hereafter 'hdz') (Figures 2 and 3). Within the shale-dominant interval (sh3) just above the hanging wall damage zone, structures resemble the dense cleavage development seen in sh1 and sh2 but are more disturbed due to increasing faults and fractures (Figure 3). Most of the fractures, faults, and mineral veins in the hanging wall are nearly parallel to the dip and strike of the bedding and cleavage, which is approximately $30^{\circ}$ toward the SE. Local azimuthal variations and dip changes occasionally appear, and NWtrending structures are sporadically distributed. At the hanging wall damage zone (38 to $41.3 \mathrm{mbgs}$ ), azimuthal variations and dip changes become more significant, as cataclastic fragmentation and sandstone boudinage appear characteristically toward the fault core.

The overall number of faults, fractures, breccias, and mineral veins (hereafter termed 'fracture density') per $1 \mathrm{~m}$ is larger within the sandstone-dominant intervals (18 per $1 \mathrm{~m}$ ) than that of the shale-dominant intervals (13 per $1 \mathrm{~m})$. It is notable that the thickness of the fracture zones in the sandstone-dominant intervals (2.7 to $5.5 \mathrm{~m})$ is smaller than that observed in the shaledominant intervals (2.3 to $18.6 \mathrm{~m}$ ) (Figure 4 ). The fracture density values for each interval are shown in Table 1. Though faults, fractures, and mineral veins are

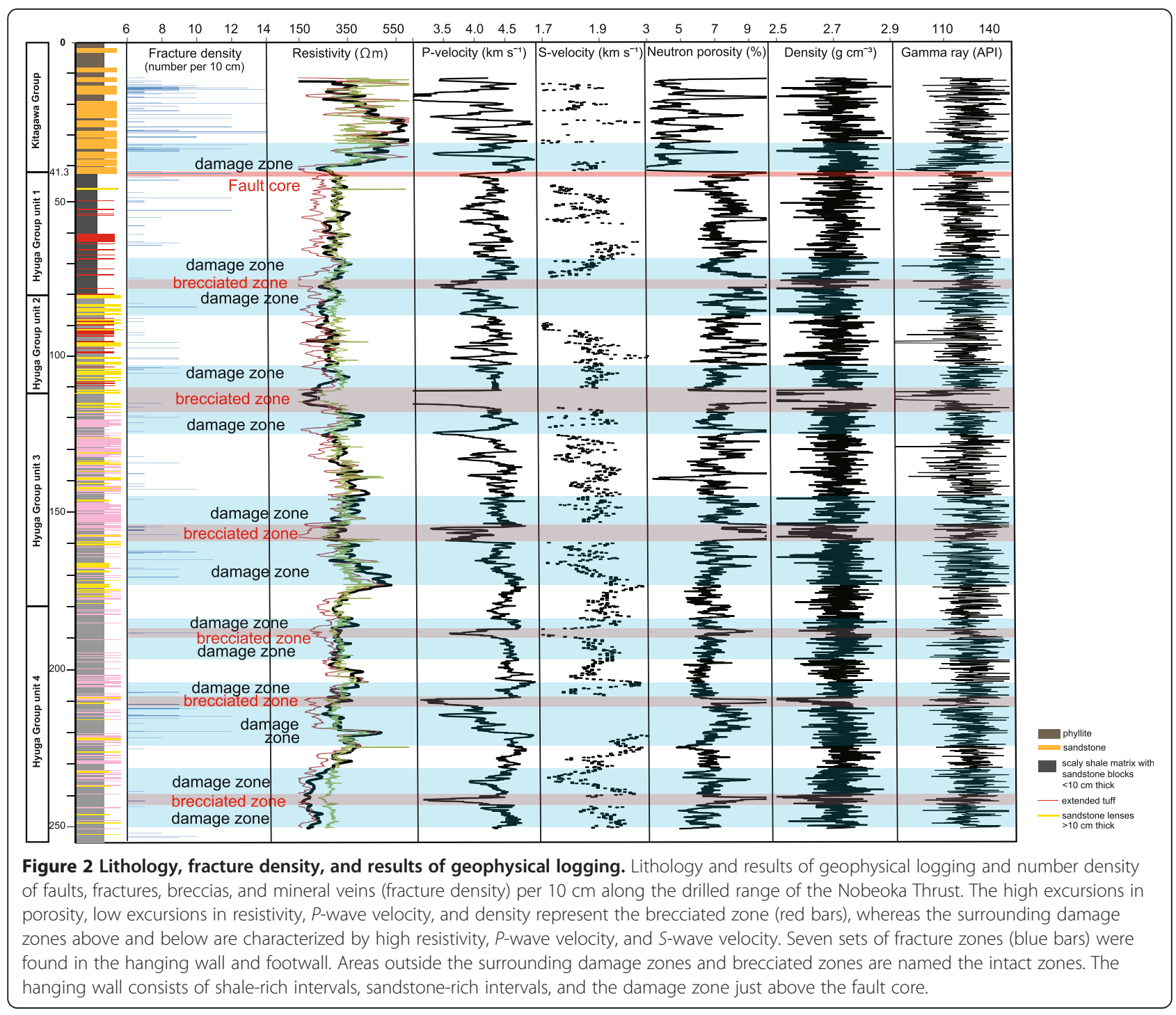




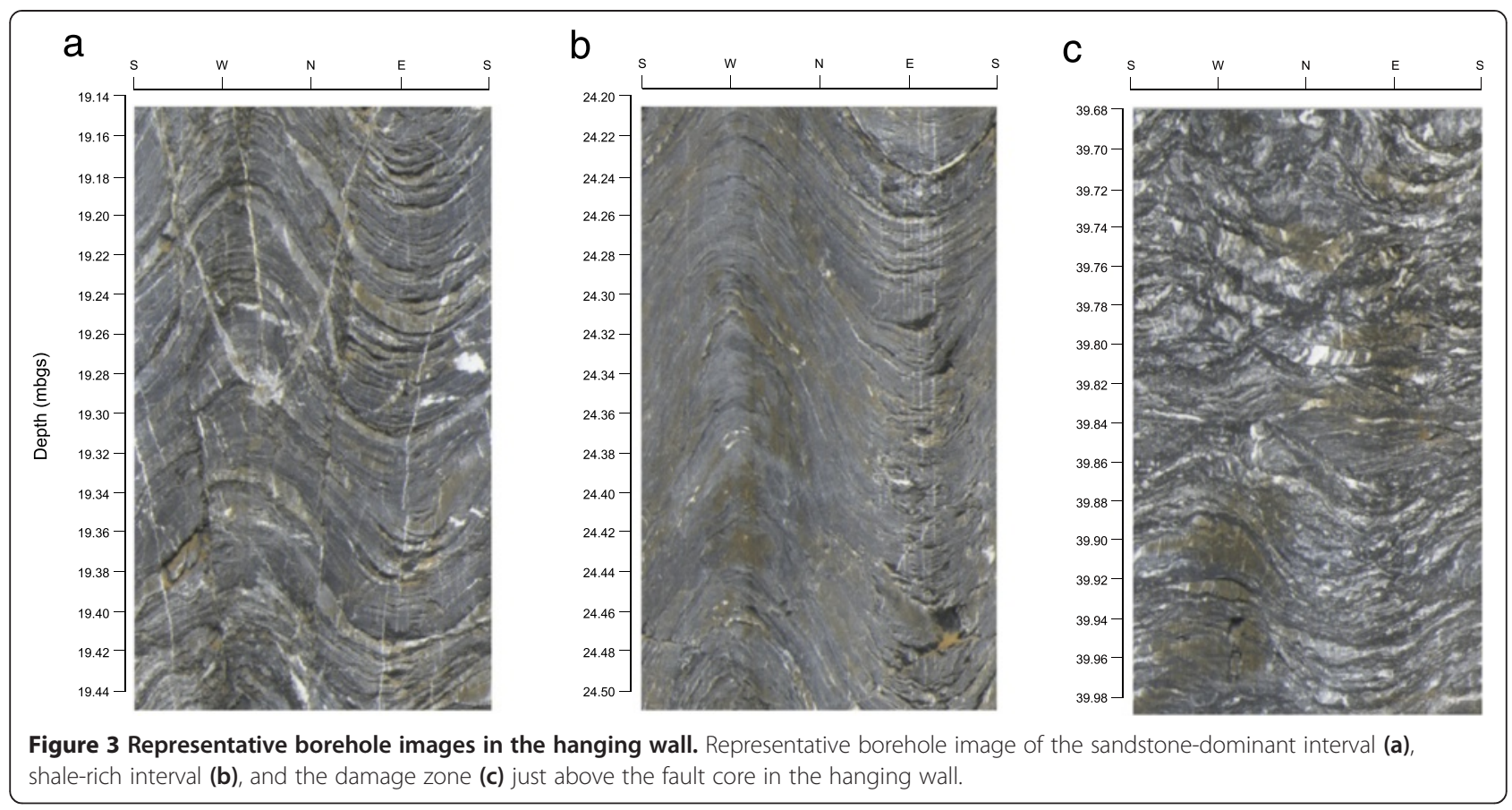

abundant in the sandstone-dominant intervals, high excursions of porosity in the hanging wall such as those at 10 to $10.86 \mathrm{~m}, 11.5$ to $11.84 \mathrm{~m}$, and 15.35 to $15.52 \mathrm{~m}$ coincide with the breccias that are all within the shale-dominant intervals.

The sandstone-dominant intervals have lower electric resistivity (356 $\Omega \mathrm{m}), P$-wave velocity $\left(4.0 \mathrm{~km} \mathrm{~s}^{-1}\right)$,

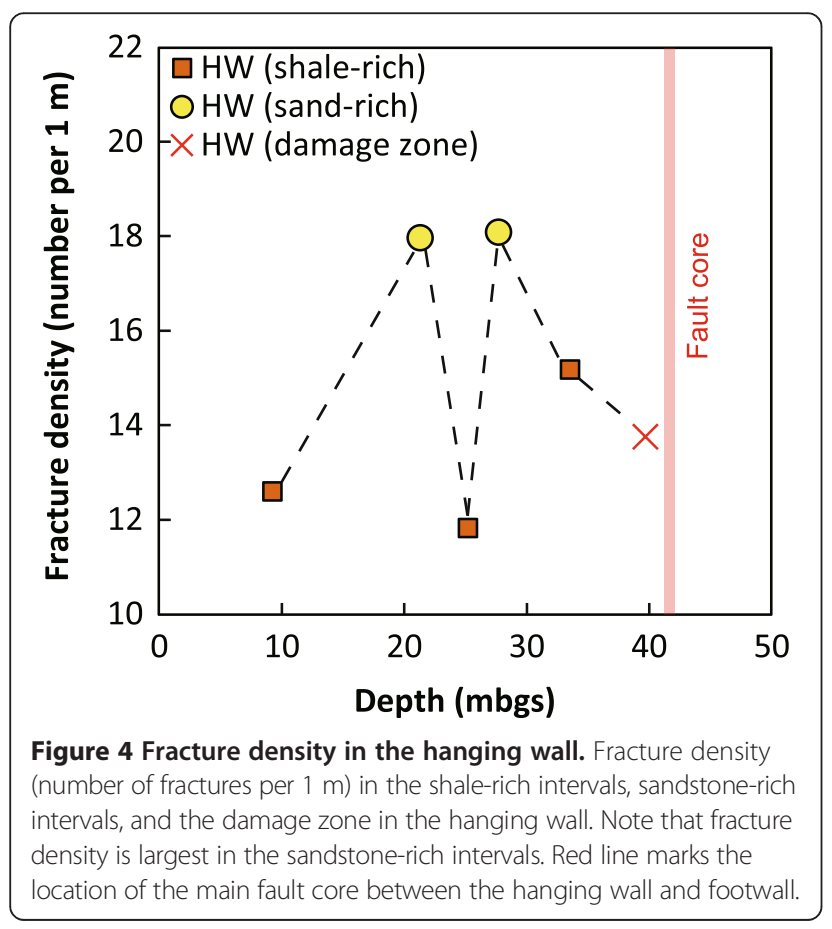

density $\left(2.69 \mathrm{~g} \mathrm{~cm}^{-3}\right)$, natural gamma ray (119.7 API), and higher neutron porosity (5.0\%) compared to the shale-dominant intervals $\left(420 \Omega \mathrm{m}, 4.3 \mathrm{~km} \mathrm{~s}^{-1}\right.$, $2.70 \mathrm{~g} \mathrm{~cm}^{-3}, 120$ API, 4.0\%) (Figure 5). The physical property values for each interval are presented in Table 1 . The hanging wall damage zone, in contrast, has the lowest resistivity (263 $\Omega \mathrm{m}$ ), neutron porosity (3.7\%), and natural gamma rays (111 API), and the highest $P$-wave velocity $\left(4.6 \mathrm{~km} \mathrm{~s}^{-1}\right)$ and density $\left(2.74 \mathrm{~g} \mathrm{~cm}^{-3}\right)$ (Figure 5 ). Note that the shale-rich zones have the highest porosity, resistivity, and $S$-wave velocity values and the lowest $P$-wave velocity values compared to the other zones (Figure 6).

The cross-plot between resistivity and porosity for the hanging wall damage zone $(<35 \mathrm{mbgs})$ above the fault core follows an approximate exponential relationship of Archie's law, with a cementation exponent $m=0.887$ (Figure 7). However, below $35 \mathrm{mbgs}$, the values are scattered and resistivity decreases abruptly with a drop in porosity at $41.3 \mathrm{mbgs}$.

A detailed description of the structure and physical properties of the hanging wall damage zone is presented in the 'Additional file 2'.

\section{Intact zone, brecciated zone, and the surrounding damage zone in the footwall}

Below the hanging wall damage zone, the fault core consists of approximately 50 -cm-thick cataclasite at a depth of 41 mbgs, composed of angular to subangular breccias of sandstone and quartz veins, floating in a shale matrix with no discernible fabric. The orientation of the Nobeoka 
Table 1 Values of fracture density and physical properties for each interval in the hanging wall

\begin{tabular}{|c|c|c|c|c|c|c|c|c|}
\hline Interval hanging wall & $\begin{array}{l}\text { Depth } \\
\text { (mbgs) }\end{array}$ & $\begin{array}{l}\text { Fracture density } \\
\text { (number per } 1 \text { m) }\end{array}$ & $\begin{array}{l}\text { Porosity } \\
(\%)\end{array}$ & $\begin{array}{l}\text { Resistivity } \\
(\Omega \mathrm{m})\end{array}$ & $\begin{array}{l}\text { Density } \\
\left(\mathrm{g} \mathrm{cm}-{ }^{3}\right)\end{array}$ & $\begin{array}{l}\text { P-wave velocity } \\
\left(\mathrm{km} \mathrm{s}-{ }^{1}\right)\end{array}$ & $\begin{array}{l}\text { Gamma } \\
\text { ray (API) }\end{array}$ & $\begin{array}{l}\text { Cementation } \\
\text { exponent } m\end{array}$ \\
\hline Shale-dominant (sh1) & 0 to 18.6 & 13 & 5.6 & 361 & 2.72 & 3.7 & 126 & 1.31 \\
\hline Shale-dominant (sh2) & 24.1 to 26.4 & 12 & 4.0 & 568 & 2.73 & 4.4 & 125 & 1.31 \\
\hline Shale-dominant (sh3) & 29.1 to 38.1 & 15 & 4.7 & 452 & 2.73 & 4.3 & 124 & 1.31 \\
\hline Sandstone-dominant (sd1) & 18.6 to 24.1 & 18 & 5.2 & 393 & 2.71 & 4.0 & 127 & 0.56 \\
\hline Sandstone-dominant (sd2) & 26.4 to 29.1 & 18 & 5.7 & 396 & 2.72 & 4.1 & 121 & 0.56 \\
\hline Damage zone (hdz) & 38.1 to 41.3 & 14 & 3.7 & 263 & 2.74 & 4.6 & 111 & 0.89 \\
\hline
\end{tabular}

Depth, fracture density (number of fractures per $1 \mathrm{~m}$ ), neutron porosity, resistivity, density, $P$-wave velocity, natural gamma ray values, and Archie's cementation exponent $m$ for the shale-dominant intervals, sandstone-dominant intervals, and the damage zone above the fault core in the hanging wall are presented.

Thrust strikes NNW and dips ENE at $30^{\circ}$ to $50^{\circ}$, nearly parallel to the bedding and cleavage in the hanging wall.

The footwall (41.3 to $255 \mathrm{mbgs}$ ) is composed of the Hyuga Group consisting of foliated cataclasite of scaly shale, tuffaceous shale, sandstone, and acidic tuff. Four lithologic units are classified in the drilled range of the footwall, based on the abundance of sandstone, silt, tuff, and its structures, although lithology and structure do not vary significantly along the cored depth (Figure 2). The description of lithology, orientation of structures, and physical properties within each unit are summarized ('Additional file 2').

The footwall in the drilled range consists of six sets of fracture zones ( 66.77 to $85.7 \mathrm{mbgs}, 95$ to $124 \mathrm{mbgs}$, 134.1 to $174 \mathrm{mbgs}, 184.6$ to $196.6 \mathrm{mbgs}, 201.8$ to 221.2 mbgs, and 222.5 to 247.3 mbgs) within each lithologic unit (Figure 2). The thicknesses of the fracture zones are $18.9 \mathrm{~m}, 29.0 \mathrm{~m}, 39.9 \mathrm{~m}, 12.0 \mathrm{~m}, 19.4 \mathrm{~m}$, and $24.8 \mathrm{~m}$, respectively. The fracture zones are responsible for the change in orientations among the lithologic units ('Additional file 2'). All of the fracture zones include a 'brecciated zone' intensively broken in the center, sandwiched by 'surrounding damage zones' with abundant cohesive faults, mineral veins, and sandstone blocks (Figures 2 and 8). These fracture zones were observed in both cores and borehole images and thus are not likely to be drilling-induced structures. Here, we call the areas outside the fracture zones the intact zones' (Figures 2 and 8). Note that the intact zones contain both bedding (cleavage)-parallel and/or bedding-cutting fractures, faults, and mineral veins that are sporadically distributed but are occasionally cut by the surrounding damage zones and brecciated zones, as shown by the change in orientation (Table 2). Particular orientations in the brecciated zones could not be recognized from the structures, but all of the six brecciated zones are associated with surrounding damage zones (see detailed descriptions in 'Additional file 2'). The fracture density for each lithologic unit ranges between 17 and 24 per $1 \mathrm{~m}$ and generally decreases with distance from the fault core (Table 2, Figure 9). The surrounding damage zone has the largest total fracture distribution except near the main fault core, where the intact zone has the largest fracture density. The fracture density values for each fracture zone are presented in Table 2.

The fracture zones are clearly identified by physical property transitions. The brecciated zones (the center of the fracture zones) are characterized by low resistivity excursions ( 80 to $210 \Omega \mathrm{m}$ ), P-wave velocity (2.3 to $3.6 \mathrm{~km} \mathrm{~s}^{-1}$ ), density (2.08 to $\left.2.65 \mathrm{~g} \mathrm{~cm}^{-3}\right)$, natural gamma rays (94 to $128 \mathrm{API}$ ), and high excursions of neutron porosity $(8.4 \%$ to $10.9 \%)$ and caliper as shown in Figures 2 and 10 and Table 2. Notably, comparing geophysical logging data with density of fractures, faults, and mineral veins per $10 \mathrm{~cm}$ along the depth, high excursions are found in electric resistivity (228 to $330 \Omega \mathrm{m}), P$-wave velocity $\left(4.2\right.$ to $\left.4.5 \mathrm{~km} \mathrm{~s}^{-1}\right), S$-wave velocity (1.8 to $2.5 \mathrm{~km} \mathrm{~s}^{-1}$ ), and density (2.71 to $2.73 \mathrm{~g} \mathrm{~cm}^{-3}$ ) that correspond to an increase in structures above and below the brecciated zones (Figures 2 and 10). These areas correspond to the surrounding damage zones (Figures 2 and 10). In contrast, physical properties in the intact zones are moderate (226 to 282 $\Omega \mathrm{m}, V p: 4.2$ to $4.6 \mathrm{~km} \mathrm{~s}^{-1}, V s: 1.7$ to $2.2 \mathrm{~km} \mathrm{~s}^{-1}, 2.71$ to $2.73 \mathrm{~g} \mathrm{~cm}^{-3}, 6.4 \%$ to $7.6 \%$ ) (Figures 2 and 8 ). The physical property values for each fracture zone are presented in Table 2.

It is clear from Figure 11 that in areas of high fracture density, the surrounding damage zones tend to have higher $P$-wave velocity, electric resistivity, and density values and lower porosity compared to the other zones. Note that, compared to the other zones, maximum density, SN resistivity, and natural gamma ray values are highest and the minimum porosity values are lowest at the intact zones (Figure 11).

The cross-plot between resistivity and porosity at each footwall damage zone follows the approximate exponential relationship of Archie's law (Figures 12 and 13). The obtained cementation exponents of the surrounding damage zones and intact zones average 0.93 and 0.78 , respectively. Values for the upper and lower half of each fracture zone are shown in Table 2. 

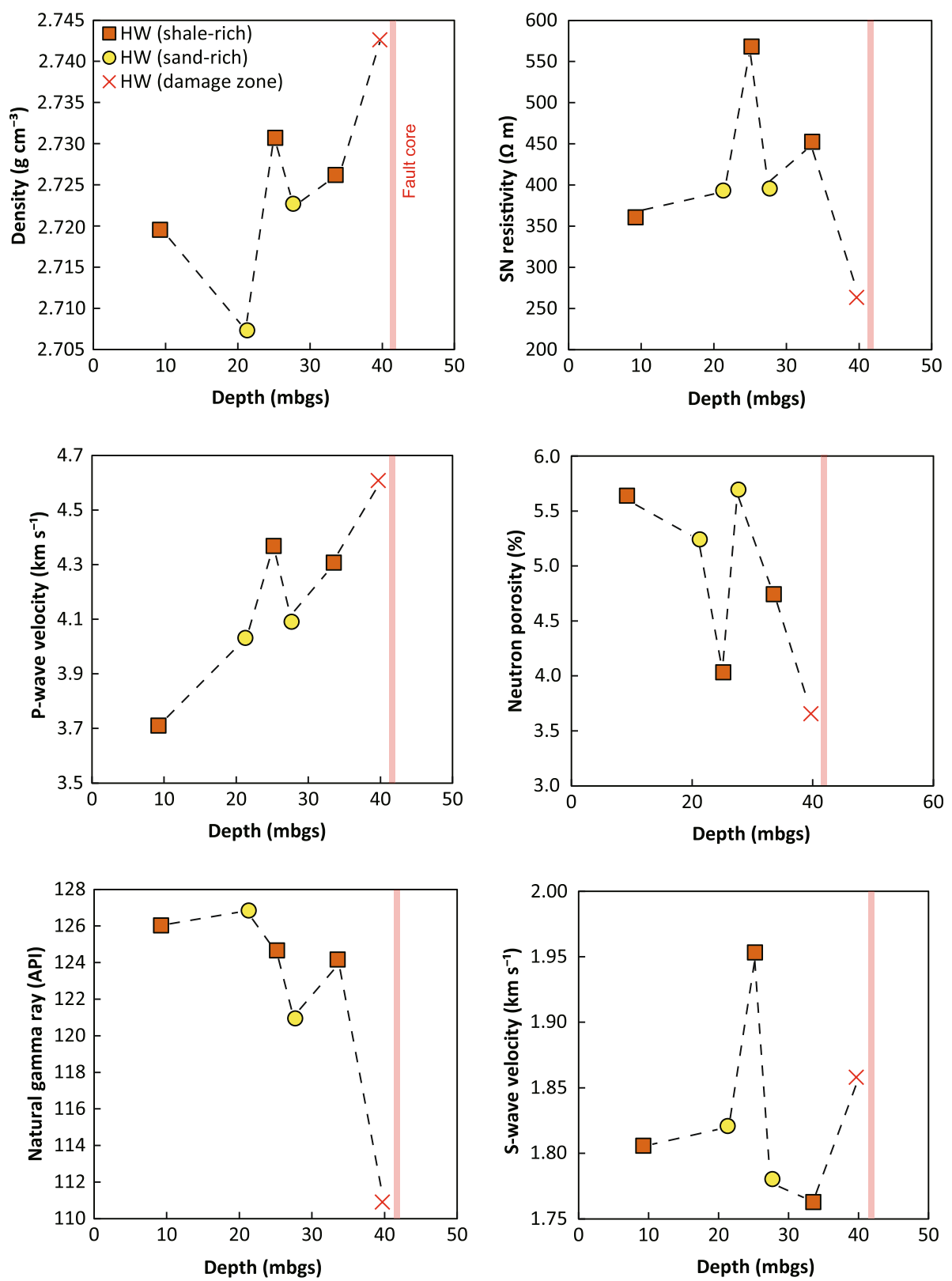

Figure 5 Physical properties in the hanging wall. Average density, resistivity, P-wave velocity, neutron porosity, natural gamma rays, and S-wave velocity in the shale-rich intervals, sandstone-rich intervals, and the damage zone in the hanging wall. Red line marks the location of the main fault core between the hanging wall and footwall.

A detailed description of physical properties and structures for each damage zone are presented in the 'Additional file 2'.

\section{Discussion}

\section{Lithology dependence of deformation patterns in the} hanging wall and the footwall

The deformation patterns in the hanging wall clearly differ among the shale-dominant intervals, sandstonedominant intervals, and the damage zone above the fault core. Cohesive faults and mineral veins are concentrated in the sandstone-dominant zones, whereas breccias occur in the shale-dominant intervals (Figures 3, 4, and 5). This suggests that brittle deformation is dominant in the sandstone-rich zones and that ductile or less brittle deformation occurs in the shale-rich sections. The fracture zones developed in the sandstone-rich intervals tend to be thinner ( 2.7 to $5.5 \mathrm{~m}$ ) than those in the shale-dominant intervals (2.3 to $18.6 \mathrm{~m}$ ), which indicates differences in slip rate, coseismic/aseismic deformation, 

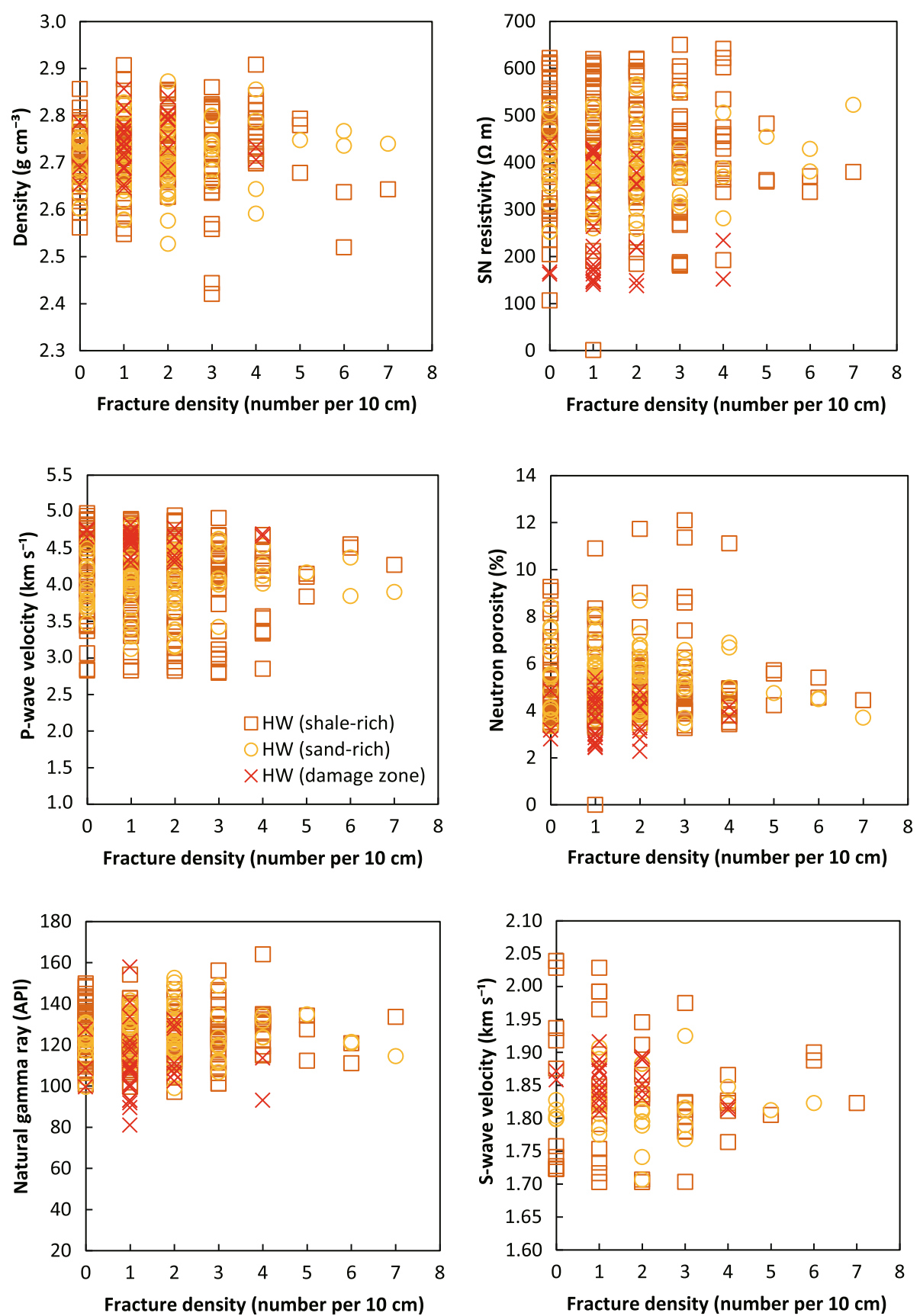

Figure 6 Cross-plot between fracture density and physical properties in the hanging wall. Cross-plot between fracture density (number of fractures per $10 \mathrm{~cm}$ ) and physical properties (density, resistivity, P-wave velocity, neutron porosity, natural gamma rays, and S-wave velocity) in the shale-dominant intervals, sandstone-dominant intervals, and the damage zone in the hanging wall.

and/or displacement. Foliation and cleavage are highly deformed in the shale-dominant interval (sh3) and in the hanging wall damage zone just above the fault core, which is associated with an increase in sandstone and a general decrease in natural gamma rays (Figure 5, Table 1). The shale-rich zones may have been weaker than the sandstone-rich zones and experienced abrasion during deformation near the fault core, whereas the relatively stronger sandstone-rich zones deformed cataclastically. The increase in resistivity, $P$-wave velocity, and density and the decrease in neutron porosity with depth above sh2 represent normal compaction, but below sh3, resistivity, $P$-wave velocity, and density decrease toward the hanging wall damage zone, corresponding to an increase in faults and fractures in this horizon (Figures 4 and 5). Within the hanging wall damage zone, however, resistivity, 


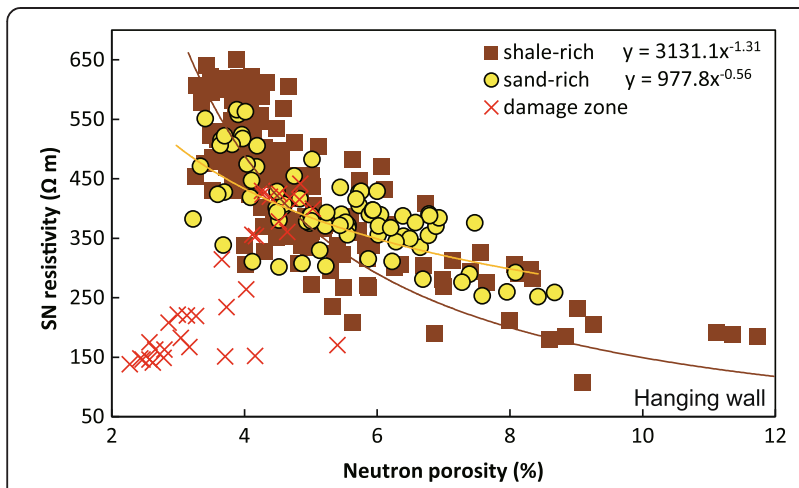

Figure 7 Cross-plot between porosity and resistivity and the approximate curve of Archie's law in the hanging wall. Cross-plot between porosity and resistivity and the approximate curve of Archie's law in the hanging wall (shale-dominant interval, sandstone-dominant interval, damage zone) for each lithologic unit. The power index of the approximate curve is Archie's $m$ parameter.

$P$-wave velocity, and density increase, while porosity decreases, despite an increase in sandstone. This may account for the densification and fabric intensification through mechanical processes such as shear compaction and/or grain fining that occurs near the fault core (Hamahashi et al. 2013).

The six fracture zones observed in the footwall all include brecciated zones in the center, surrounded by damage zones, which have the highest fault/fracture distribution and have likely overprinted the intact zones (Figures 2, 8 and 9). The deformation pattern in the footwall represents a state of shear localization and a multiple damage zone system. It is notable that sandstone is more abundant in the surrounding damage zones and shale is richer in the intact zones, which is also indicated by lower natural gamma ray values in the surrounding damage zones. Thus, shear localization may initiate more easily in the sandstone-rich zones, and an intensively deformed fault core (breccia) will be concentrated within these zones. The thickness of the fracture zones in the footwall is variable, ranging between $12 \mathrm{~m}$ and $39.9 \mathrm{~m}$.

Compared to the footwall damage zones, the hanging wall has thinner shear zones of 2.3 to $18.6 \mathrm{~m}$ thickness, possibly due to higher porosity and lower shear strength in the footwall as a result of deep burial in the hanging wall and accumulation of displacement across the fault. In addition to the contrast in physical properties across the fault, the hanging wall may have developed thinner shear zones because strain was partitioned between the preexisting turbiditic sequence of alternating shale/sandstone-dominant intervals, and deformation was concentrated in the sandstone-rich intervals. In contrast, faults and fractures are more sporadically distributed in the footwall likely due to less partitioning of strain within the sandstone block-in-shale matrix structure, creating thicker shear zones as a whole.

\section{Implications of the relationship between fracture density and physical properties in the damage zones of the Nobeoka Thrust}

The damage zones seen in the cores of the Nobeoka Thrust in both the hanging wall and footwall are of two

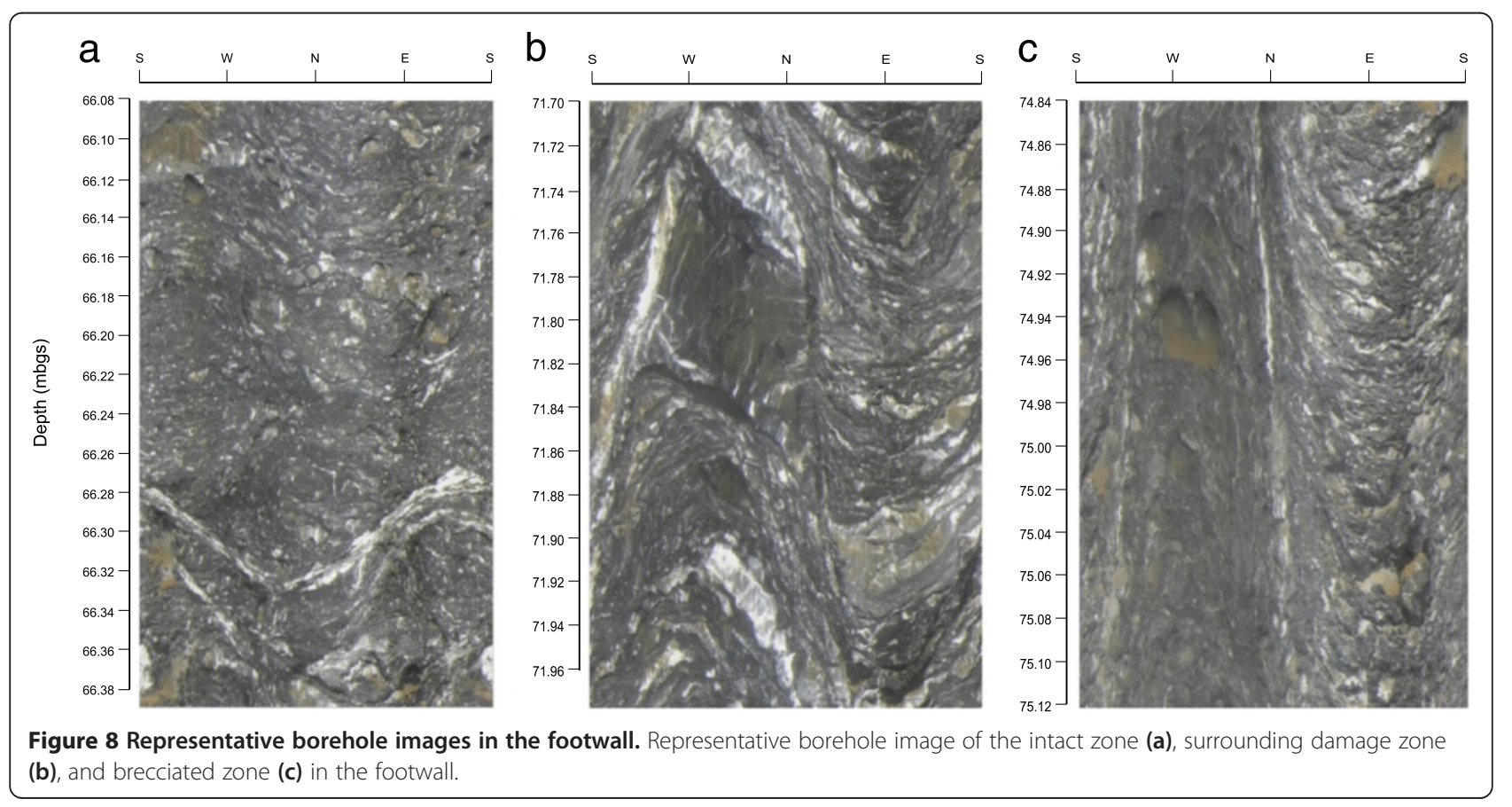


Table 2 Values of fracture density and physical properties for each interval in the footwall

\begin{tabular}{|c|c|c|c|c|c|c|c|c|}
\hline Interval footwall & Depth (mbgs) & $\begin{array}{l}\text { Fracture density } \\
\text { total/density } \\
\text { (number per } 1 \mathrm{~m} \text { ) }\end{array}$ & $\begin{array}{l}\text { Porosity } \\
\text { (\%) }\end{array}$ & $\begin{array}{l}\text { Resistivity } \\
(\Omega \mathrm{m})\end{array}$ & $\begin{array}{l}\text { Density } \\
\left(\mathrm{g} \mathrm{cm}-{ }^{3}\right)\end{array}$ & $\begin{array}{l}P \text {-wave } \\
\text { velocity } \\
\left(\mathrm{km} \mathrm{s}-{ }^{1}\right)\end{array}$ & $\begin{array}{l}\text { Gamma } \\
\text { ray (API) }\end{array}$ & $\begin{array}{l}\text { Cementation } \\
\text { exponent } m\end{array}$ \\
\hline \multicolumn{9}{|l|}{$\begin{array}{l}\text { Footwall unit } 1 \\
\text { (42.1 to } 80 \text { mbgs) }\end{array}$} \\
\hline Intact zone & 41.8 to 66.7 & $245 / 10$ & 7.6 & 232 & 2.72 & 4.25 & 123 & 0.60 \\
\hline Damage zone & 66.7 to 75,80 to 85.7 & $102 / 7$ & 7.8 & 241 & 2.71 & 4.34 & 124 & $\begin{array}{l}\text { Upper: } 1.07, \\
\text { Lower: } 0.92\end{array}$ \\
\hline Brecciated zone & 75 to 80 & $43 / 9$ & 10.9 & 166 & 2.65 & 3.94 & 125 & 0.82 \\
\hline \multicolumn{9}{|l|}{$\begin{array}{l}\text { Footwall unit } 2 \\
\text { (80 to } 112 \text { mbgs) }\end{array}$} \\
\hline Intact zone & 85.7 to 95 & $96 / 11$ & 7.6 & 226 & 2.70 & 4.25 & 125 & 0.95 \\
\hline Damage zone & 95 to 112,115 to 124 & $249 / 10$ & 7.6 & 251 & 2.70 & 4.19 & 123 & $\begin{array}{l}\text { Upper: } 0.80 \\
\text { Lower: } 0.96\end{array}$ \\
\hline Brecciated zone & 112 to 115 & $25 / 9$ & 31 & 80 & 2.08 & 2.29 & 94 & 0.36 \\
\hline \multicolumn{9}{|l|}{$\begin{array}{l}\text { Footwall unit } 3 \\
\text { (112 to } 180 \text { mbgs) }\end{array}$} \\
\hline Intact zone & 124 to 134,174 to 180 & $121 / 8,354 / 9$ & 7.2 & 281 & 2.72 & 4.29 & 126 & 1.00 \\
\hline Damage zone & 134 to 157,159 to 174 & $354 / 9$ & 7.2 & 330 & 2.71 & 4.40 & 127 & $\begin{array}{l}\text { Upper: } 1.22, \\
\text { Lower: } 0.88\end{array}$ \\
\hline Brecciated zone & 157 to 159 & $011 / 6$ & 10.9 & 168 & 2.65 & 3.96 & 128 & 0.26 \\
\hline \multicolumn{9}{|l|}{$\begin{array}{l}\text { Footwall unit 4-1 } \\
\text { (180 to } 196.6 \text { mbgs) }\end{array}$} \\
\hline Intact zone & 180 to 184.6 & $25 / 6$ & 7.1 & 255 & 2.72 & 4.39 & 126 & 0.56 \\
\hline Damage zone & 184.6 to 188,189 to 196.6 & $73 / 7$ & 6.7 & 270 & 2.73 & 4.50 & 126 & $\begin{array}{l}\text { Upper: } 1.00, \\
\text { Lower: } 1.00\end{array}$ \\
\hline Brecciated zone & 188 to 189 & $14 / 16$ & 8.4 & 205 & 2.69 & 4.10 & 124 & 0.72 \\
\hline \multicolumn{9}{|l|}{$\begin{array}{l}\text { Footwall unit 4-2 } \\
\text { (196.6 to } 221.2 \text { mbgs) }\end{array}$} \\
\hline Intact zone & 196.6 to 201.8 & $54 / 11$ & 6.4 & 283 & 2.71 & 4.57 & 128 & 0.79 \\
\hline Damage zone & 201.8 to 210,212 to 221.2 & $167 / 10$ & 7.0 & 281 & 2.72 & 4.34 & 128 & $\begin{array}{l}\text { Upper: } 0.95 \text {, } \\
\text { Lower: } 1.12\end{array}$ \\
\hline Brecciated zone & 210 to 212 & $20 / 10$ & 9.4 & 209 & 2.59 & 3.55 & 123 & 0.49 \\
\hline \multicolumn{9}{|l|}{$\begin{array}{l}\text { Footwall unit } 4-3 \\
\text { (221.2 to } 255 \text { mbgs) }\end{array}$} \\
\hline Intact zone & 221.2 to $222.5,247.3$ to 255 & $73 / 8$ & 6.4 & 234 & 2.73 & 4.61 & 126 & 0.79 \\
\hline Damage zone & 222.5 to 242,243 to 247.3 & $179 / 8$ & 6.6 & 228 & 2.73 & 4.46 & 127 & $\begin{array}{l}\text { Upper: } 1.42, \\
\text { Lower: } 0.86\end{array}$ \\
\hline Brecciated zone & 242 to 243 & $13 / 13$ & 10.2 & 101 & 2.65 & 3.58 & 123 & 0.58 \\
\hline
\end{tabular}

Depth, fracture total number distribution, fracture density (number of fractures per $1 \mathrm{~m}$ ), neutron porosity, resistivity, density, $P$-wave velocity, natural gamma ray values, and Archie's cementation exponent $m$ for the intact zones, surrounding damage zones, and the brecciated zones in the footwall are presented.

types: cohesive, mineral vein filled damage zones and brecciated fracture zones. The cohesive structures of the surrounding damage zones are characterized by high peaks in resistivity and $P / S$-wave velocity, representing a densification occurring within the structures, whereas the brecciated zones cause an increase in caliper and porosity and a decrease in resistivity and $P$-wave velocity, representing highly fractured intervals.

Drilling studies of active faults from $<4 \mathrm{~km}$ depth found that fault cores that contain a single fault core surrounded by subsidiary faults occur across lithologic discontinuities at the Alpine Fault (Sutherland et al. 2012), Punchbowl Fault (Chester et al. 1993), Carboneras Fault (Faulkner and Rutter 2003), and the Median Tectonic Line (Shigematsu et al. 2012). These large tectonic faults tend to develop $>1 \mathrm{~m}$ to few kilometers thick damage zones across metamorphic schists and sedimentary rocks. Multiple fault strands surrounded by damage zones, individually up to several meters thick, are documented to be localized within single lithologies (less than approximately $4 \mathrm{~km}$ depth) at the San Andreas Fault (Zoback et al. 2010), Wenchuan Fault (Li et al. 2013), Chelungpu Fault 


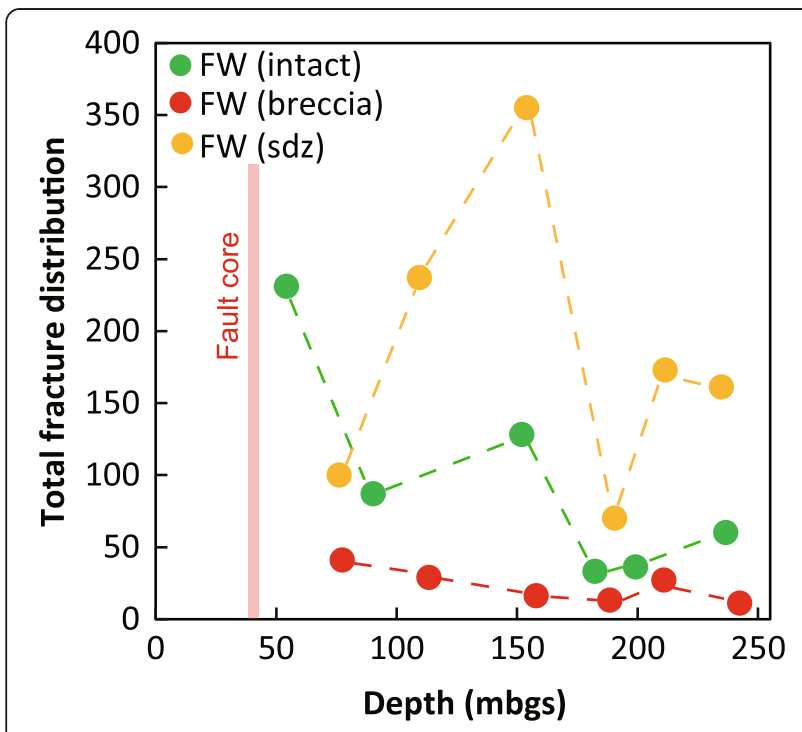

Figure 9 Total number distribution of faults, fractures, breccias, and mineral veins in the footwall. Total number distribution of faults, fractures, breccias, and mineral veins in each of the intact zones, surrounding damage zones $(\mathrm{s} d \mathrm{z})$, and the brecciated zones in the footwall. Red line marks the location of the main fault core between the hanging wall and footwall.

(Song et al. 2007), and the Nojima Fault (Tanaka et al. 2007). These strike-slip and reverse faults occur within sedimentary lithologies and exhibit fault zone thicknesses ranging from several to approximately 135 -m-thick damage zones. In the Nobeoka Thrust, a single fault core occurs between the hanging wall and footwall, but within each wall, multiple damage zones are localized near the fault core. The fault zone structure may depend largely on lithology, physical properties such as porosity, depth of formation, and the contrast across the fault (e.g., Balsamo et al. 2010; Faulkner et al. 2010). Damage zones in lowporosity rocks such as mudstone are reported to have a tendency to contain dilatant fractures (Blenkinsop 2008; Faulkner et al. 2010), whereas damage zones in higherporosity rocks such as sandstone may be characterized by structures such as compaction bands or cataclastic deformation bands (e.g., Johansen et al. 2005; Fossen et al. 2007; Faulkner et al. 2010). The shale-dominant interval in the hanging wall deformed by brecciation, and the cataclastic deformation in the sandstone-rich interval in the Nobeoka Thrust are consistent with these observations. However, the physical property transitions across the fracture zones found in this study, i.e., the densification in the surrounding damage zone inferred from high resistivity, density, $P$-wave velocity, and $S$-wave velocity around the brecciated zone, have not been reported from previous drilling studies and may be a unique characteristic of the exhumed subduction fault rocks of the Nobeoka Thrust. The coexistence of cohesive fault rock and less-cohesive fault rock in a single fault system has not been documented in previous studies, because the fault cores and damage zones observed from exhumed outcrops are usually well-consolidated due to their deep origin and surface weathering of softer structures, whereas samples taken from depth $(<4 \mathrm{~km})$ by direct drilling are often less-cohesive rocks since they come from relatively shallow depths.

In our examination of the relationship between physical properties and faults, fractures, and mineral vein density in all of the surrounding damage zones at the Nobeoka Thrust, we found that resistivity and density have a negative correlation below a fracture density value of 20 per $1 \mathrm{~m}$, indicating that deformation may have occurred in a strain-weakening manner (high resistivity to low resistivity, low porosity to high porosity) (Figure 14). Above a fracture density of 20 (per $1 \mathrm{~m}$ ), the trend is the opposite, in which resistivity increases with an increasing number of structures, indicating that deformation has occurred in a strain-hardening manner (low resistivity to high resistivity, high porosity to low porosity) (Figure 14). Similarly, though the values are variable, both $P$-wave velocity and $S$-wave velocity increase slightly above a fracture density of 20 (per $1 \mathrm{~m}$ ). Interestingly, porosity also increases in this horizon, indicating that the increase in resistivity is not necessarily due to compaction (Figure 14).

It is generally known that in a brittle-ductile regime, damage accumulation is manifested by strain hardening and is eventually characterized by strain softening (Figure 15). Rock experiments and physical property measurements suggest that shear stress and physical properties including porosity, $P$-wave velocity, electric resistivity, and permeability evolve during rock deformation (Figure 15) (e.g., Paterson and Wong 2010; Scholz 2002). In the present study, we assume that strain is accumulating toward each of the fracture zones in the Nobeoka Thrust, eventually causing strain hardening associated with the observed increases in resistivity, $P$-wave velocity, and density in the surrounding damage zone, and strain-weakening associated with the increase in porosity in the brecciated zone (Figure 15).

\section{Implications of the porosity and resistivity relationship: variations in Archie's cementation exponent $m$ in the damage zones}

Clear relationships between resistivity and porosity in the damage zones throughout the drilled range of the Nobeoka Thrust were identified from Archie's curve (Figures 7,12 , and 13). The cementation exponent $m$ is comparable among the fracture zones ranging between 0.3 and 1.3 (Tables 1 and 2). Generally, $m$ is known to be an indication for the intensity of deformation at various scales (e.g., Kozlov et al. 2012), and values obtained from sandstones and crystalline rocks lie around approximately 



Figure 10 Physical properties in the footwall. Average density, resistivity, P-wave velocity, neutron porosity, natural gamma ray, and S-wave velocity in the intact zones, surrounding damage zones (sdz), and the brecciated zones in the footwall. Red line marks the location of the main fault core between the hanging wall and footwall.

2.0 on average (e.g., Brace et al. 1965; Kozlov et al. 2012). However, values for $m$ of approximately 1 as observed at the Nobeoka Thrust have also been documented from fracture and frictional sliding experiments with saturated sandstones and crystalline rocks where a sharp decrease in resistivity corresponded closely to an increase in porosity or dilatancy under compressive stress (e.g., Brace and Orange 1968). Cracks developed during dilatancy are probably predominately oriented parallel to the axis of maximum compression (e.g., Brace and Byerlee 1967), and a rapid transition in resistivity may account for a drastic change in crack geometry (e.g., Brace et al. 1965). In contrast, larger $m$ values indicate a rapid increase in resistivity with an associated porosity decrease, which may likely occur during crack closure (e.g., Brace et al. 1965).

The fractures in each damage zone in the Nobeoka Thrust may have formed due to dilatancy and crack connectivity during deformation and faulting. Though the 



Figure 11 Cross-plot between fracture density and physical properties in the footwall. Cross-plot between fracture density (number of fractures per $10 \mathrm{~cm}$ ) and physical properties (density, resistivity, P-wave velocity, neutron porosity, natural gamma rays, and S-wave velocity) in the intact zones, surrounding damage zones (sdz), and brecciated zones in the footwall.

values for the damage zones in this study are variable, $m$ is relatively lower near the main fault core and increases with distance. The hanging wall damage zone has a relatively smaller $m$ compared to the footwall fracture zones, emphasizing that deformation is most intense in this area. Interestingly, the intact zones have smaller $m$ values compared to the surrounding damage zones, and values are well below 1.0 near the fault core, suggesting that the intact zones preserve primary deformation that was later overprinted by the surrounding damage zones, or are less compacted than the surrounding damage zones.

Fracture density in the intact zones generally decreases with distance from the main fault core, indicating that the structures in the intact zones are related to the primary fault activity of the Nobeoka Thrust (Figures 9 and 16). 

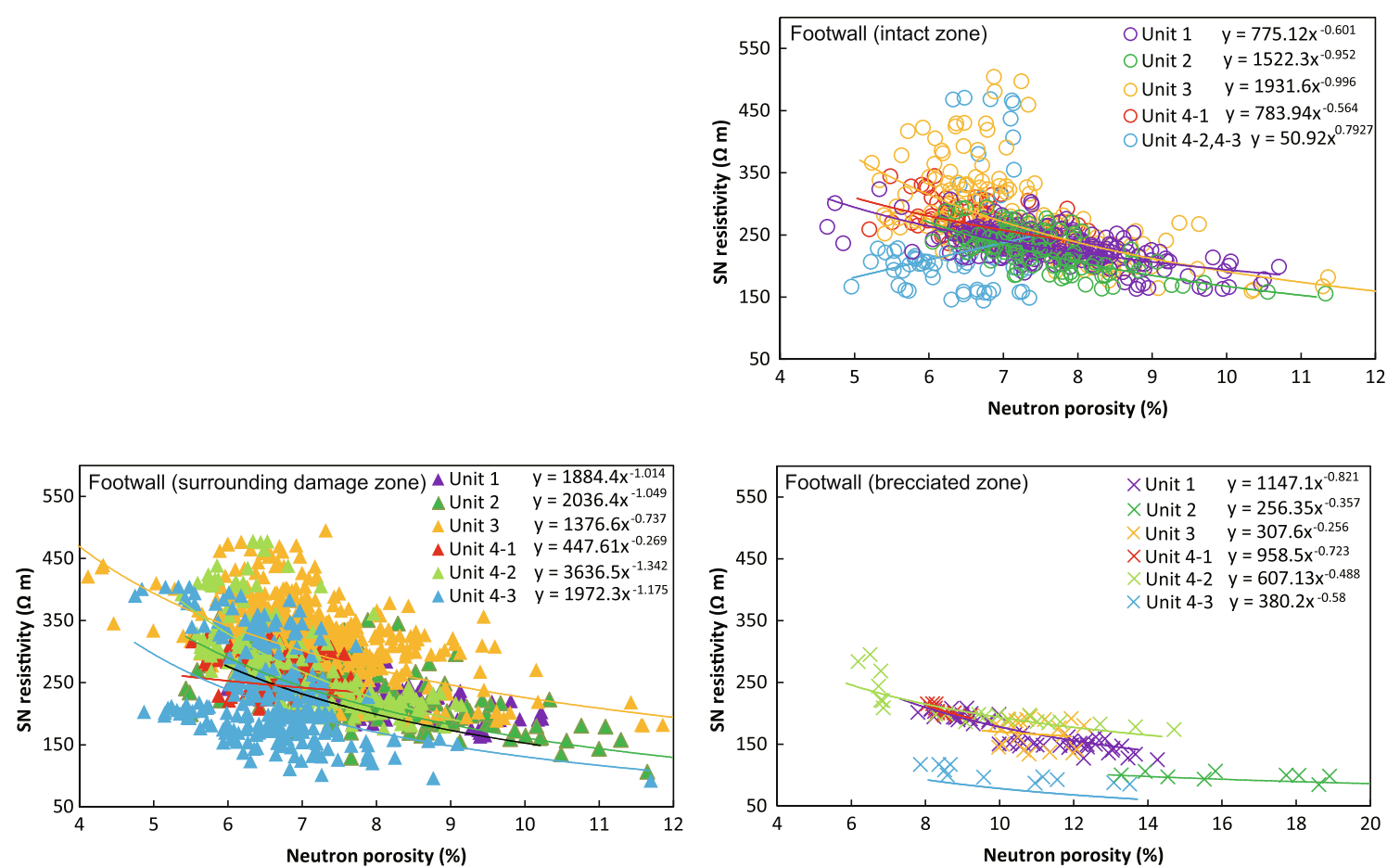

Figure 12 Cross-plot between porosity and resistivity and the approximate curve of Archie's law in the footwall. Cross-plot between porosity and resistivity and the approximate curve of Archie's law in the footwall (intact zone, surrounding damage zone, brecciated zone) for each lithologic unit. The power index of the approximate curve is Archie's $m$ parameter.

The general decrease in sandstone with distance from the main fault core may also contribute to the variations in deformation behavior. In contrast, in the surrounding damage zones above the footwall fracture zone (184.6 to $196.6 \mathrm{mbgs})$, fracture density increases with distance from the fault core (Figure 9). In this horizon, the surrounding damage zones that later overprint the intact zones are implied to have caused densification and strain hardening that may have increased with distance from the fault core (Figure 16).

\section{Evaluating the evolution of shear localization and damage zone thickness in large displacement faults in subduction zones}

Recent seismological, geological, and geodetic studies have revealed that tectonic faults act in various modes of fault slip (e.g., Collettini et al. 2011). The slip budget within seismogenic zones in subduction settings is accommodated by coseismic slip, aseismic creep, lowfrequency earthquakes, episodic volcanic/non-volcanic tremor, and slow slip events that occur along plate boundary faults (e.g., Ito and Obara 2006; Rubinstein et al. 2010). The width of the deformation zone is one of the parameters that characterize the mode of fault slip, frictional instability, displacement, and fault evolution (e.g., Rice et al. 2014). Field observations of seismic faults showed that shear deformation is often localized within principal slip zones less than a few centimeters thick, surrounded by cataclasite layers (e.g., Chester and Chester 1998; Sibson 2003). High-velocity friction experiments (e.g., Brantut et al. 2008; Kitajima et al. 2010) and numerical models (e.g., Lachenbruch 1980; Noda et al. 2009) indicate that thinner deforming zones tend to be associated with rapid temperature rise and unstable slip (velocity-weakening), whereas thicker shear zones are preferred in stable slip (velocitystrengthening).

According to the compilation by Rowe et al. (2013), subduction plate boundary faults as observed by ocean drilling and field studies in accretionary prisms at depths of $>1$ to $2 \mathrm{~km}$ tend to develop multiple strands tens of meters thick within damage zones of approximately 100 to $350 \mathrm{~m}$ thickness. However, no systematic change in the thickness of fault strands or sharp discrete faults with depth (up to approximately $15 \mathrm{~km}$ ) has been reported, and the values are variable (Rowe et al. 2013). This may also be the case for megasplay faults branching from the plate boundary such as in the Nankai Trough, where fault thickness and roughness are documented to be variable along the fault (Yamada et al. 2013). The damage zone thickness of the Nobeoka Thrust in the current study is also variable in both the hanging wall and footwall, ranging between 2.3 to $18.6 \mathrm{~m}$ and 12.0 to $39.9 \mathrm{~m}$, respectively. 

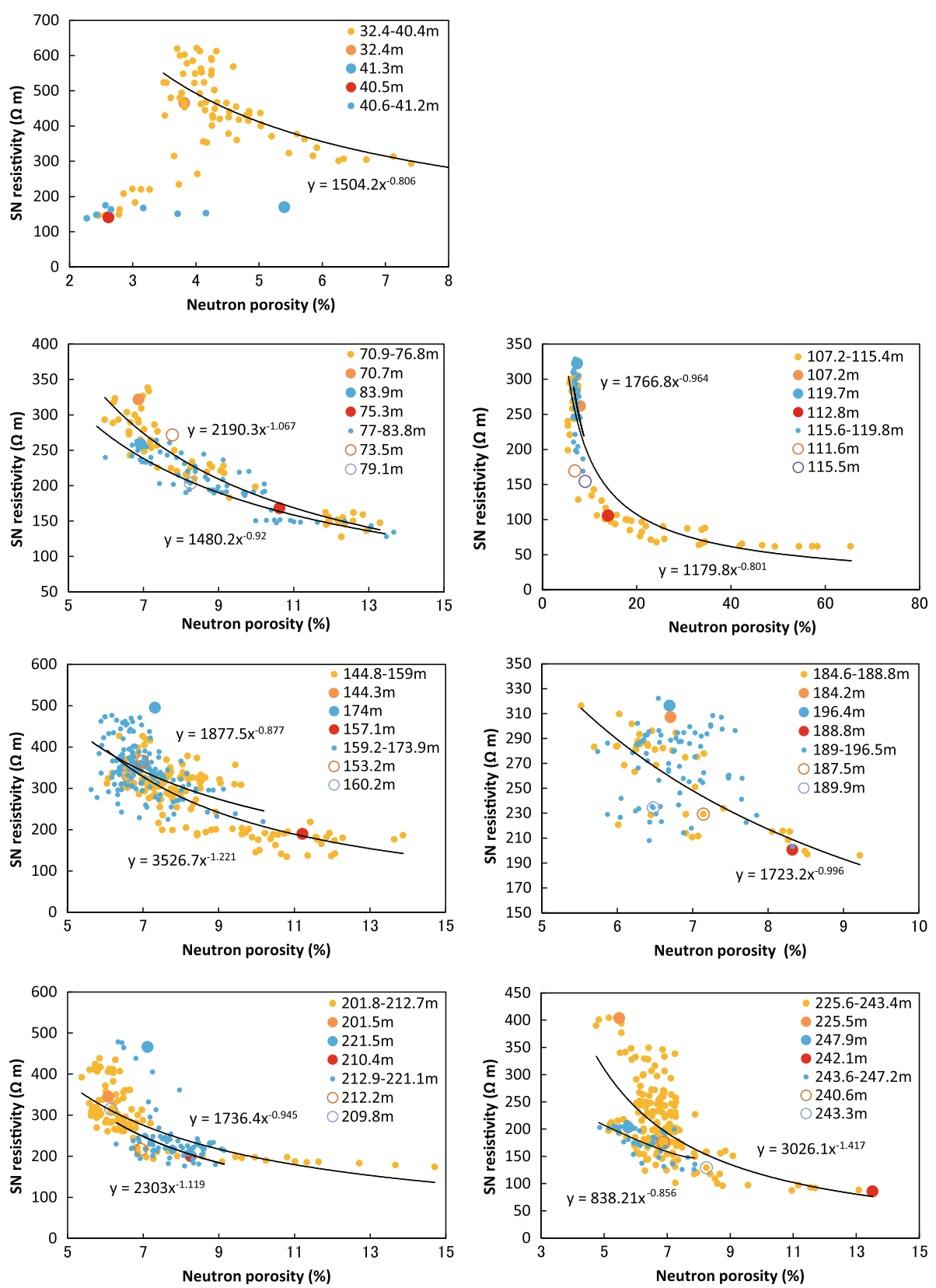

Figure 13 Cross-plot between porosity and resistivity and the approximate curve of Archie's law. Cross-plot between porosity and resistivity and the approximate curve of Archie's law for each damage zone in the hanging wall and footwall. Yellow dots: upper half of the surrounding damage zones $(\mathrm{sdz})$. Yellow circles: resistivity peak in the upper half of the sdz. Yellow-lined circles: porosity increase in the upper half of the sdz. Blue dots: lower half of the sdz. Blue circles: resistivity peak in the lower half of the sdz. Blue-lined circles: porosity increase in the lower half of the sdz. Red circles: brecciated zones. The power index of the approximate curve is Archie's $m$ parameter.

Frictional instability and mode of slip would not necessarily correspond with fault zone thickness alone, due to the heterogeneous distribution of lithologies and physical properties of the sediments. Shearing may localize where high-competent and velocity-weakening materials such as sandstone are dominant, and broadening of deformation zones may be favored in lowcompetent and velocity-strengthening materials such as mudstone (e.g., Faulkner et al. 2008; Fagereng and Sibson 2010). These observations are consistent with the damage zone structures documented from the Nobeoka Thrust in the current study, where brittle deformation is localized within the sandstone-rich damage zones. However, the damage zones observed in the current study infer densification and strain-hardening structures (cohesive faults and fractures) in the sandstone-rich 



Figure 14 Relationship between fracture density and physical properties in the hanging wall and footwall. Relationship between fracture density (number of fractures per $1 \mathrm{~m}$ ) and resistivity, P-wave velocity, S-wave velocity, porosity, and density for the surrounding damage zones $(\mathrm{sdz})$ in the hanging wall and footwall. Note that below a fracture density of 20 (per $1 \mathrm{~m})$ ), the resistivity, P-wave velocity, density, and S-wave velocity decrease with an increase in structures, implying strain-weakening. However, above a fracture density of 20 (per 1 m) (colored red), these properties increase with an increase in structures, indicating strain-hardening.

intervals and strain-weakening (brecciated structures) in the mudstone-rich intervals, which does not necessarily represent the velocity-weakening/strengthening behaviors demonstrated in frictional experiments. Sandstone-rich damage zones may weaken in the short term but may strengthen in the geologically long term and contribute to a later stage of fault activity before fossilization. In contrast, the mudstone-rich damage zones may strengthen in the short term but may develop weak structures over longer time periods, especially during exhumation. These effects may eventually create differences in damage zone thickness and influence the roles of shear localization in strain-hardening/weakening behaviors in fault zones. The characteristics of 


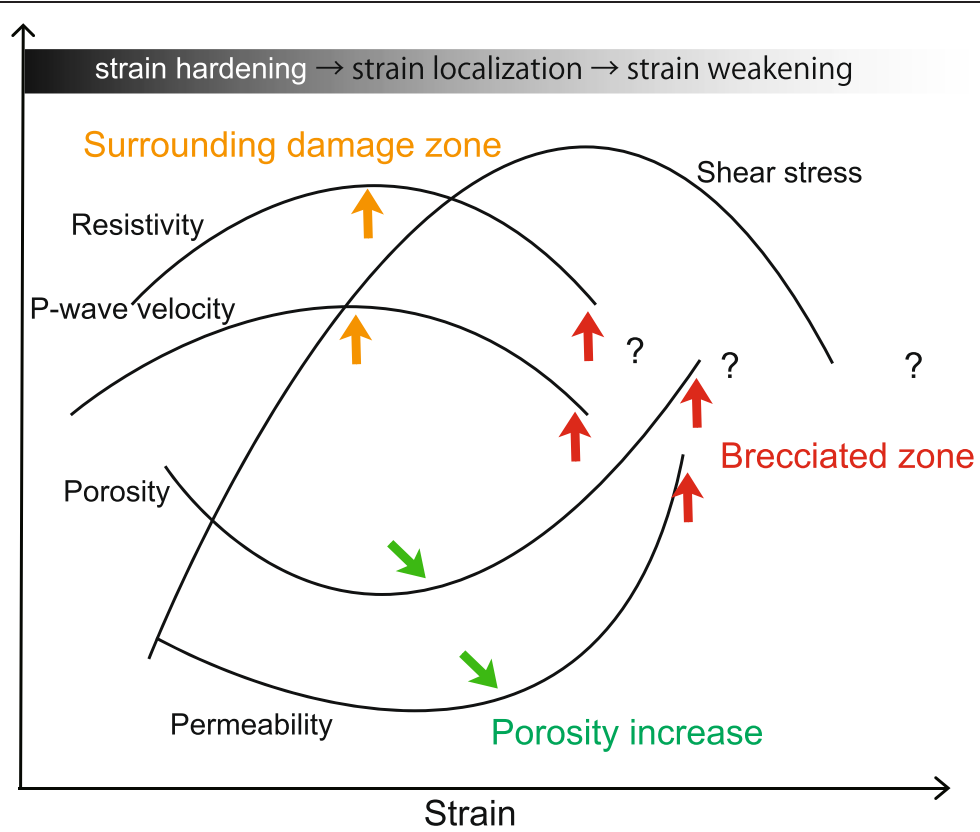

Figure 15 Schematic model of physical properties and shear-stress transition during rock deformation (e.g., Paterson and Wong 2010; Scholz 2002). The vertical axes are porosity, resistivity, P-wave velocity, permeability, and shear stress of the rocks as labeled for each curve. The increases in resistivity, and P-wave velocity, and the decrease in porosity during strain hardening and strain localization may correspond to the surrounding damage zone in the present study (arrows in orange), whereas the point where resistivity and P-wave velocity begin to decrease and the porosity begins to increase during localization is shown by the green arrows. The state of strain weakening may correspond to the brecciated zones (red arrows).

megasplay faulting may be explained by the lithology dependence of deformation and the difference in concentration and partitioning of faults within these structures resulting in a variable damage zone thickness across the thrust at the seismogenic zone as inferred in the present study. Though the shear zone thickness varies, a similar process of shear localization and densification in the surrounding damage zone is observed in both the hanging wall and footwall of the Nobeoka Thrust.

\section{Conclusions}

To investigate the mechanical properties and deformation patterns of megathrusts in subduction zones, we studied the damage zone structures of the Nobeoka Thrust, an exhumed megasplay fault in the Kyushu Shimanto Belt, using drill cores and geophysical logging data obtained during the Nobeoka Thrust Drilling Project.

- The hanging wall damage zone above the fault core and the six sets of fracture zones in the footwall of the Nobeoka Thrust all include 'brecciated zones', intensively

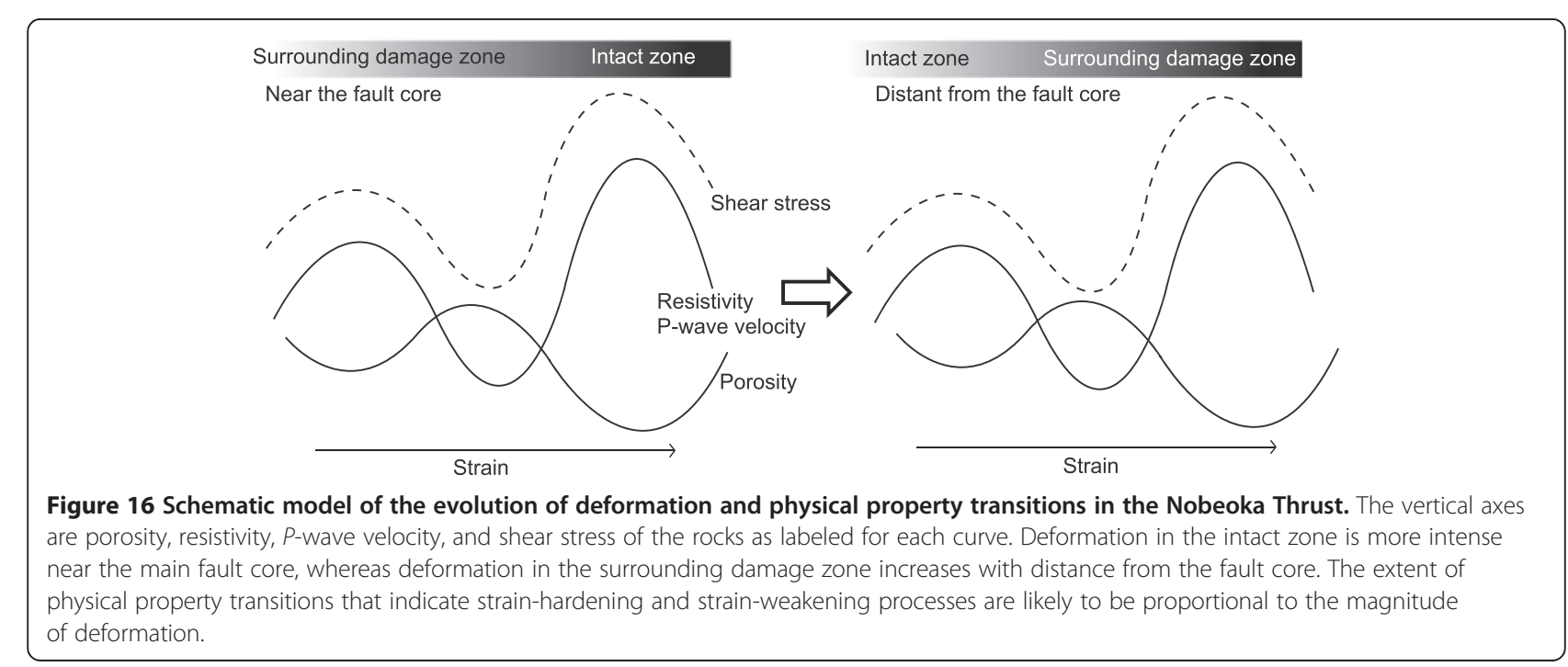


broken in the center, sandwiched by 'surrounding damage zones' with abundant cohesive faults, mineral veins, and sandstone blocks. The surrounding damage zones are associated with an increase in resistivity, $P$-wave velocity, and density and a decrease in porosity. The deformation in the surrounding damage zones is inferred to have occurred in a strain-hardening manner during shear localization, whereas a strain-weakened, intensively deformed brecciated zone developed in the center.

- Sandstone is more abundant in the surrounding damage zones and shale is more common in the intact zone, indicating that shear localization may initiate more easily in the sandstone-rich zones. The fracture zones in the hanging wall are thinner in the sandstone-rich zones ( 2.7 to $5.5 \mathrm{~m}$ ) compared to the shale-dominant intervals ( 2.3 to $18.6 \mathrm{~m}$ ), which indicates a preference for coseismic slip in the former and aseismic deformation in the latter, and differences in slip rate and/or displacement between the two. The hanging wall has thinner shear zones of 2.3 to $18.6 \mathrm{~m}$ thickness compared to the footwall damage zones ranging between 12.0 to $39.9 \mathrm{~m}$ in thickness, possibly due to higher porosity and lower shear strength in the footwall as a result of deep burial and accumulation of displacement. In addition to the contrast in physical properties across the thrust, the difference in damage zone thickness may have occurred because the faults and fractures in the hanging wall were concentrated and partitioned between the preexisting turbiditic sequence of alternating shale-dominant intervals and sandstone-dominant intervals, whereas in the footwall, faults and fractures were more sporadically distributed throughout the sandstone block-in-matrix cataclasites.

- Damage zone thickness is variable in both the hanging wall and footwall, likely due to the heterogeneous distribution of lithologies and physical properties of the sediments. Thin shear zones may localize in high-competent and velocity-weakening materials such as sandstone, whereas thick deformation zones may be favored in low-competent and velocity-strengthening materials such as mudstone. However, the damage zones observed in the current study infer densification and strain-hardening structures in the sandstone-rich intervals and strain-weakening in the mudstone-rich intervals, which does not necessarily represent the velocity-weakening of sandstone and velocity-strengthening behaviors of mudstone demonstrated in frictional experiments. Sandstone-rich damage zones may weaken in the short term but may strengthen in the geologically long term and contribute to a later stage of fault activity before fossilization. In contrast, the mudstone-rich damage zones may strengthen in the short term but develop weak structures over longer time periods, especially during exhumation.

A splay fault may evolve and be characterized by physical property contrasts, a lithology-dependence of deformation, and differences in concentration and partitioning of faults within the structures, resulting in variable damage zone thickness in the hanging wall and footwall. Our study of deformation patterns observed in the Nobeoka Thrust may contribute to the understanding of strain-hardening/ weakening behaviors of sediments along megathrusts over geologically long timescales.

\section{Additional files}

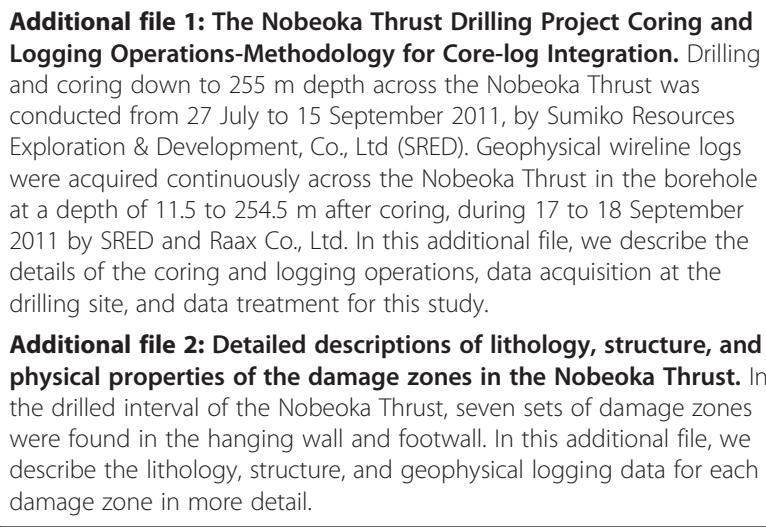

Additional file 2: Detailed descriptions of lithology, structure, and physical properties of the damage zones in the Nobeoka Thrust. In the drilled interval of the Nobeoka Thrust, seven sets of damage zones were found in the hanging wall and footwall. In this additional file, we describe the lithology, structure, and geophysical logging data for each damage zone in more detail.

\section{Competing interests}

The authors declare that they have no competing interests.

\section{Authors' contributions}

All authors have made substantial contributions to the acquisition of the geological data of the drill cores during the Nobeoka Thrust Drilling Project. $\mathrm{MH}$ carried out the analysis of core-log integration and the drafting of the manuscript. GK, AY, SS, and YH have provided helpful comments to the conception of the data. All authors read and approved the final manuscript.

\section{Acknowledgements}

This work was supported by MEXT Science Research Grant 21107005, JSPS Grant 23244099 (research A), and the Center for Advanced Marine Core Research, Kochi University (CMCR) Nationwide Joint Use System (12A007, 12B006). We are grateful to Y. Mizuochi, K. Hase, T. Akashi, and the technicians from SRED and RAAX for performing the coring and logging during the Nobeoka Thrust Drilling Project. We acknowledge S. Hina and M. Eida for their contributions to core observations during drilling. We also thank T. Kanda of Miyazaki University for the hospitality during our stay at the Nobeoka Marine Science Station.

\section{Author details}

'Department of Earth and Planetary Science, Graduate School of Science, The University of Tokyo, 7-3-1 Hongo, Bunkyo-ku, Tokyo 113-0033, Japan. ${ }^{2}$ Kochi Institute for Core Sample Research, Japan Agency for Marine-Earth Science and Technology, 200 Monobe Otsu, Nankoku City, Kochi 783-8502, Japan. ${ }^{3}$ Atmosphere and Ocean Research Institute, The University of Tokyo, 5-1-5, Kashiwanoha, Kashiwa-shi, Chiba 277-8564, Japan. ${ }^{4}$ Institute for 
Research on Earth Evolution, Japan Agency for Marine-Earth Science and Technology, 2-15 Natsushima-choYokosuka, Kanagawa 237-0061, Japan.

${ }^{5}$ Earth and Planetary System Science, Department of Natural History Sciences, Graduate School of Science, Hokkaido University, N10 W8, Sapporo 060-0810, Japan. ${ }^{6}$ Department of Earth and Environmental Sciences, Graduate School of Science and Engineering, Kagoshima University, 1-21-35 Korimoto, Kagoshima 890-0065, Japan. ${ }^{7}$ Faculty of Education, Tokyo Gakugei University, 4-1-1 Nukui-kitamachi, Koganei-shi, Tokyo 184-8501, Japan. ${ }^{8}$ Department of Applied Science, Faculty of Science, Kochi University, 2-5-1 Akebono-cho, Kochi-shi, Kochi 780-8520, Japan.

Received: 10 March 2014 Accepted: 14 January 2015

Published online: 24 February 2015

\section{References}

Archie GE (1942) The electrical Resistivity log as an aid in determining some reservoir characteristics. Pet Trans AIME 146:54-62

Balsamo F, Storti F, Salvini F, Silva A, Lima C (2010) Structural and petrophysical evolution of extensional fault zones in low-porosity, poorly lithified sandstones of the Barreiras Formation, NE Brazil. J Struct Geol 32(11):1806-1826

Blenkinsop TG (2008) Relationships between faults, extension fractures and veins, and stress. J Struct Geol 30(5):622-632

Boulton C, Carpenter BM, Toy V, Marone C (2012) Physical properties of surface outcrop cataclastic fault rock, Alpine Fault, New Zealand. Geochem Geophys Geosyst 13:Q01018, doi:10.1029/2011GC003872

Brace WF, Byerlee JD (1967) Recent experimental studies of brittle fracture of rocks. Proc. 8th Symp Rock Mechanics, Minneapolis, Minnesota, p 58

Brace WF, Orange AS (1968) Electrical resistivity changes in saturated rocks during fracture and frictional sliding. J Geophys Res 73(4):1433-1445

Brace WF, Orange AS, Madden TM (1965) The effect of pressure on the electrical resistivity of water-saturated crystalline rock. J Geophys Res 70(20):5669

Brantut N, Schubnel A, Rouzaud JN, Brunet F, Shimamoto T (2008) High-velocity frictional properties of a clay-bearing fault gouge and implications for earthquake mechanics. J Geophys Res 113, B10401, doi:10.1029/2007JB005551

Brodsky EE, Kanamori H (2001) Elasohydrodynamic lubrication of faults. J Geophys Res 106:16357-16374

Chester FM, Chester JS (1998) Ultracataclasite structure and friction processes of the Punchbowl fault, San Andreas System, California. Tectonophysics 295:199-221

Chester FM, Logan JM (1986) Implications for mechanical properties of brittle faults from observation of the Punchbowl fault zone, California. Pure Appl Geophys 124:79-106, doi:10.1007/BF00875720

Chester FM, Evans JP, Biegel RL (1993) Internal structure and weakening mechanisms of the San Andreas fault. J Geophys Res 98:771-786, doi:10.1029/92JB01866

Collettini C, Holdsworth RH (2004) Fault zone weakening and character of slip along low angle normal faults: insights from the Zuccale fault, Elba, Italy. J Geol Soc London 161:1039-1051

Collettini C, Niemeijer A, Viti C, Smith SAF, Marone C (2011) Fault structure, frictional properties and mixed-mode fault slip behavior. Earth Planet Sci Lett 311:316-327, doi:10.1016/j.epsl.2011.09.020

De Bresser JHP, Ter Heege JH, Spiers CJ (2001) Grain size reduction by dynamic recrystallization; Can it result in major rheological weakening? Int J Earth Sci 90:28-45

Di Toro G, Han R, Hirose T, De Paola N, Nielsen S, Mizoguchi K, Ferri F, Cocco M, Shimamoto T (2011) Fault lubrication during earthquakes. Nature 471:494-498

Ewing RP, Hunt AG (2006) Dependence of the electrical conductivity on saturation in real porous media. Vadose Zone J 5(2):731-741

Fagereng A, Sibson RH (2010) Melange rheology and seismic style. Geology 38:751-754, doi:10.1130/G30868.1

Faulkner DR, Rutter EH (2003) The effect of temperature, the nature of the pore fluid, and subyield differential stress on the permeability of phyllosilicate-rich fault gouge. J Geophys Res 108((B5) 2227):1-12

Faulkner DR, Mitchell TM, Rutter EH, Cembrano J (2008) On the structure and mechanical properties of large strike-slip faults, in Wibberley CAJ et al. eds, The internal structure of fault zones: Implications for mechanical and fluid-flow properties. Geol Soc London SP 299:139-150, doi:10.1144/SP299.9

Faulkner DR, Jackson CAL, Lunn RJ, Schulz RW, Shipton ZK, Wibberley CAB, Withjack MO (2010) A review of recent developments concerning the structure, mechanics, and flow properties of fault zones. J Struct Geol 32:1557-1575

Fossen H, Schultz RA, Shipton ZK, Mair K (2007) Deformation bands in sandstone: a review. J Geol Soc 164:755-769

Fukuchi R, Fujimoto K, Kameda J, Hamahashi M, Yamaguchi A, Kimura G, Hamada Y, Hashimoto Y, Kitamura Y, Saito S (2014) Changes in illite crystallinity within an ancient tectonic boundary thrust caused by thermal, mechanical, and hydrothermal effects: an example from the Nobeoka Thrust, southwest Japan. Earth Planets Space 66:116, doi:10.1186/1880-5981-66-116

Gueydan F, Leroy YM, Jolivet L, Agard P (2003) Analysis of continental midcrustal strain localization induced by microfracturing and reaction-softening. J Geophys Res 108(B2):2064, doi:10.1029/2001JB000611

Hamahashi M, Saito S, Kimura G, Yamaguchi A, Fukuchi R, Kameda J, Hamada Y, Kitamura Y, Fujimoto K, Hashimoto Y, Hina S, Eida M (2013) Contrasts in physical properties between the hanging wall and footwall of an exhumed seismogenic megasplay fault in a subduction zone - an example from the Nobeoka Thrust Drilling Project. Geochem Geophys Geosyst 14:5354-5370, doi:10.1002/2013GC004818

Hara H, Kimura K (2008) Metamorphic and cooling history of the Shimanto accretionary complex, Kyushu, Southwest Japan: implications for the timing of out-of-sequence thrusting. Island Arc 17:546-559

Imai I, Teraoka Y, Okumura K (1971) Geologic structure and metamorphic zonation of the northeastern part of the Shimanto terrane in Kyushu, Japan. J Geol Soc Jpn 77:207-220

Imber J, Holdsworth RE, Butler CA, Strachan RA (2001) A reappraisal of the Sibson-Scholz fault zone model: the nature of the frictional-viscous ("brittle-ductile") transition along a long-lived, crustal-scale fault. Outer Hebrides, Scotland. Tectonics 20:601-624

Ito Y, Obara K (2006) Dynamic deformation of the accretionary prism excites very low frequency earthquakes. Geophys Res Lett 33(L02311):1-4

Jefferies SP, Holdsworth RE, Shimamoto T, Takagi H, Lloyd GE (2006) Origin and mechanical significance of foliated cataclasitic rocks in the cores of crustal-scale faults: examples from the Median Tectonic Line, Japan. J Geophys Res $111(B 12303): 1-17$, doi:10.1029/2005JB004205

Johansen TES, Fossen H, Kluge R (2005) The impact of syn-faulting porosity reduction on damage zone architecture in porous sandstone: an outcrop example from the Moab Fault, Utah. J Struct Geol 27(8):1469-1485

Kameda J, Raimbourg H, Kogure T, Kimura G (2011) Low-grade metamorphism around the down-dip limit of seismogenic subduction zones; Example from an ancient accretionary complex in the Shimanto Belt, Japan. Tectonophysics 502:383-392, doi:10.1016/j.tecto.2011.02.010

Kimura K (1998) Out-of-sequence thrust of an accretionary complex. Mem Geol Soc Japan 50:131-146

Kimura G, Hamahashi M, Okamoto S, Yamaguchi A, Kameda J, Raimbourg H, Hamada Y, Yamaguchi H, Shibata T (2013) Hanging wall deformation of a seismogenic megasplay fault in an accretionary prism: the Nobeoka Thrust in southwest Japan. J Struct Geol 52:136-147, doi.org/10.1016/ j.jsg.2013.03.015

Kitajima H, Chester JS, Chester FM, Shimamoto T (2010) High-speed friction of disaggregated ultracataclasite in rotary shear: characterization of frictional heating, mechanical behavior, and microstructure evolution. J Geophys Res 115(B08408):1-21, doi:10.1029/2009JB007038

Kondo H, Kimura G, Masago H, Ohmori-lkehara K, Kitamura Y, Ikesawa E, Sakaguchi A, Yamaguchi A, Okamoto S (2005) Deformation and fluid flow of a major out-of-sequence thrust located at seismogenic depth in an accretionary complex: Nobeoka Thrust in the Shimanto Belt, Kyushu, Japan. Tectonics 24(TC6008):1-16

Kozlov B, Schneider MH, Montaron B, Lagues M, Tabeling P (2012) Archie's law in microsystems. Trans Porous Med 95:1-20, doi:10.1007/s11242-012-0029-6

Lachenbruch AH (1980) Frictional heating, fluid pressure, and the resistance to fault motion. J Geophys Res 85:6097-6112

Leloup PH, Ricard Y, Battaglia J, Lacassin R (1999) Shear heating in continental strike-slip shear zones: model and field examples. Geophys J Int 136(1):19-40

Li H, Wang H, Xu Z, Si J, Pei J, Li T, Huang Y, Song SR, Kuo LW, Sun Z, Chevalier ML, Liu D (2013) Characteristics of the fault-related rocks, fault zones and the principal slip zone in the Wenchuan Earthquake Fault Scientific Drilling Project Hole-1 (WFSD-1). Tectonophysics 584:23-42, doi.org/10.1016/ j.tecto.2012.08.021

Logan JM, Higgs NG, Friedman M (1981) Laboratory studies on natural fault gouge from the U.S. Geological Survey Dry Lake Valley No. 1 Well, San Andreas Fault zone, In: Mechanical Behavior of Crustal Rocks; The Handin 
Volume, In: Carter NL, Friedman M, Logan JM, Stearns DW (Eds). Geophys Monogr Am Geophys Un 24:121-134

Maruyama S, Isozaki Y, Kimura G, Terabayashi M (1997) Paleogeographic maps of the Japanese Islands: Plate tectonic synthesis from $750 \mathrm{Ma}$ to the present.Island. Arc 6(1):121-142

Montaron B (2009) Connectivity theory - a new approach to modeling non-Archie rocks. Petrophysics 50(2):102-115

Niemeijer AR, Spiers CJ (2005) Influence of phyllosilicates on fault strength in the brittle-ductile transition; insights from rock analogue experiments. In: Bruhn D, Burlin L (eds) High Strain Zones: Structure and Physical Properties, vol 245, Geol Soc London SP., pp 303-327

Noda H, Dunham EM, Rice JR (2009) Earthquake ruptures with thermal weakening and the operation of major faults at low overall stress levels. J Geophys Res 114(B07302):1-27, doi:10.1029/2008JB006143

Okamoto S, Kimura G, Takizawa S, Yamaguchi H (2006) Earthquake fault rock indicating a coupled lubrication mechanism. e-Earth 1:23-28

Okamoto S, Kimura G, Yamaguchi A, Yamaguchi H, Kusaba Y (2007) Generation depth of the Pseudotachylyte from an Out-of Sequence thrust in accretionary prism-geothermobarometric evidence. Sci Drill Special Issue 1:47-50

Park JO, Tsuru T, Kodaira S, Cummins PR, Kaneda Y (2002) Splay fault branching along the Nankai subduction zone. Science 297(5584):1157-1160, doi:10.1126/science.1074111

Paterson MS, Wong TF (2010) Experimental rock deformation - the brittle field, 2nd edn. Springer-Verlag GmbH, Germany

Raimbourg H, Shibata T, Yamaguchi A, Yamaguchi H, Kimura G (2009) Horizontal shortening versus vertical loading in accretionary prisms. Geochem Geophys Geosyst 10(Q04007):1-17, doi:10.1029/2008GC002279

Ramsay JG (1992) Some geometrical problems of ramp-flat thrust models. In: McClay KR (ed) Thrust Tectonics. CRC Press, Boca Raton, Fla, pp 191-200

Ramsay JG, Huber MI (1987) Reverse faults - fault geometry and morphology. In: The Techniques of Modern Structural Geology: 2: Folds and Fractures. Academic, London, pp 521-527

Rice JR, Rudnicki JW, Platt JD (2014) Stability and localization of rapid shear in fluid-saturated fault gouge: 1. Linearized stability analysis. J Geophys Res-Sol Ea 119(5):4311-4333, doi:10.1002/2013JB010710

Rowe CD, Moore JC, Remitti F, IODP Expedition 343/343T Scientists (2013) The thickness of subduction plate boundary faults from the seafloor in the seismogenic zone. Geology 41:991-994, doi:10.1130/G34556.1

Rubinstein JL, Shelly DR, Ellsworth WL (2010) Non-volcanic tremor: a window into the roots of fault zones. In: Cloetingh S, Negendank J (eds) New Frontiers in Integrated Solid Earth Sciences., pp 287-314

Saffer DM, Tobin HB (2011) Hydrogeogy and mechanics of subduction zone forearcs: fluid flow and pore pressure. Annu Rev Earth Planet Sci 39:157-186

Scholz CH (2002) The mechanics of earthquakes and faulting. Cambridge University Press, Cambridge

Shigematsu N, Fujimoto K, Tanaka N, Furuya N, Mori H, Wallis S (2012) Internal structure of the Median Tectonic Line fault zone, SW Japan, revealed by borehole analysis. Tectonophysics 532:103-118

Sibson RH (2003) Thickness of the seismic slip zone. B Seismol Soc Am 93:1169-1178, doi:10.1785/0120020061

Smith SAF, Collettini C, Holdsworth RE (2008) Recognizing the seismic cycle along ancient faults: CO2-induced fluidization of breccias in the footwall of a sealing low-angle normal fault. J Struct Geol 30:1034-1046

Song SR, Kuo LW, Yeh EC, Wang CY, Hung JH, Ma KF (2007) Characteristics of the lighology, fault-related rocks and fault zone structures in the TCDP Hole-A. Terr Atmos Ocean Sci 18:243-269

Stewart M, Holdsworth RE, Strachan RA (2000) Deformation processes and weakening mechanisms within the frictional-viscous transition zone of major crustal-scale faults: insights from the Great Glen Fault Zone, Scotland. J Struct Geol 22:543-560

Suppe J (1983) Geometry and kinematics of fault-bend folding. Am J Sci 283:684-721

Sutherland R, Toy VG, Townend J, Cox SC, Eccles JD, Faulkner DR, Prior DJ, Norris RJ, Mariani E, Boulton C, Carpenter BM, Menzies CD, Little TA, Hasting M, De Pascale GP, Langridge RM, Scott HR, Z. Reid Lindroos, Fleming B, Kopf AJ (2012) Geology 40 (12): 1143-1146. doi:10.1130/G33614.1.

Taira A, Tokuyama H, Soh W (1989) Accretion tectonics and evolution of Japan. In: Ben-Avraham Z (ed) The Evolution of the Pacific Ocean Margins. Oxford University Press, New York, pp 100-123

Tanaka H, Omura K, Matsuda T, Ikeda R, Kobayashi K, Murakami M, Shimada K (2007) Architectural evolution of the Nojima fault and identification of activated slip layer of Kobe earthquake. J Geophys Res 112(B07304):1-20, doi:10.1029/2005JB003977

Tsuji T, Kimura G, Okamoto S, Kono F, Mochinaga H, Saeki T, Tokuyama H (2006) Modern and ancient seismogenic out-of-sequence thrusts in the Nankai Accretionary prism: comparison of laboratory-derived physical properties and seismic reflection data. Geophys Res Lett 33(L18309):1-5

Tsuji T, Tokuyama H, Costa Pisani P, Moore G (2008) Effective stress and pore pressure in the Nankai accretionary prism off the Muroto Peninsula, southwestern Japan. J Geophys Res 113(B11401):1-19, doi:10.1029/ 2007JB005002

Ujiie K, Tsutsumi A (2010) High-velocity frictional properties of clay-rich fault gouge in a megasplay fault zone, Nankai subduction zone. Geophys Res Lett 37(L24310):1-5

Wibberley CAJ, Shimamoto T (2005) Earthquake slip weakening and asperities explained by thermal pressurization. Nature 436:689-692

Yamada Y, Masui R, Tsuji T (2013) Characteristics of a tsunamigenic megasplay fault in the Nankai Trough. Geophys Res Lett 40:4594-4598, doi;10.1002/ grl.50888

Yamaguchi A, Cox SF, Kimura G, Okamoto S (2011) Dynamic changes in fluid redox state associated with episodic fault rupture along a megasplay fault in a subduction zone. Earth Planet Sci Lett 302:369-377

Zoback MD, Hickman S, Ellsworth W (2010) Scientific drilling into the San Andreas fault zone. Eos Trans AGU 92(22):197-199, doi:10.1029/ 2010EO220001

\section{Submit your manuscript to a SpringerOpen ${ }^{\circ}$ journal and benefit from:}

- Convenient online submission

- Rigorous peer review

- Immediate publication on acceptance

- Open access: articles freely available online

- High visibility within the field

- Retaining the copyright to your article

Submit your next manuscript at $>$ springeropen.com 